FEDERAL RESERVE BANK OF SAN FRANCISCO

WORKING PAPER SERIES

\title{
Intergenerational Linkages in Household Credit
}

\author{
Andra C. Ghent \\ University of Wisconsin-Madison \\ Marianna Kudlyak \\ Federal Reserve Bank of San Francisco
}

December 2016

Working Paper 2016-31

http://www.frbsf.org/economic-research/publications/working-papers/wp2016-31.pdf

\section{Suggested citation:}

Ghent, Andra C., Marianna Kudlyak. 2016. "Intergenerational Linkages in Household Credit” Federal Reserve Bank of San Francisco Working Paper 2016-31.

http://www.frbsf.org/economic-research/publications/working-papers/wp2016-31.pdf

The views in this paper are solely the responsibility of the authors and should not be interpreted as reflecting the views of the Federal Reserve Bank of San Francisco or the Board of Governors of the Federal Reserve System. 


\title{
Intergenerational Linkages in Household Credit
}

\author{
Andra C. Ghent \\ University of Wisconsin- \\ Madison \\ ghent@wisc.edu
}

\author{
Marianna Kudlyak \\ Federal Reserve Bank of San \\ Francisco \\ marianna.kudlyak@sf.frb.org
}

First Draft: November 5, 2015

This Draft: December 21, 2016

\begin{abstract}
We document novel, economically important correlations between children's future credit risk scores, default, and homeownership status and their parents' credit characteristics measured when the children are in their late teens. A one standard deviation higher parental credit risk score when the child is 19 is associated with a 24 percent reduction in the likelihood that the child goes bankrupt by age 29, a 36 percent lower likelihood of other serious default, a 35 point higher child credit score, and a 23 percent higher chance of the child becoming a homeowner. The linkages persist after controlling for parental income. The linkages are stronger in cities with lower intergenerational income mobility, implying that common factors might drive both. Existing measures of state-level educational policy have limited effects on the strength of the linkages. Evidence from a sample of siblings suggests that the linkages might be largely due to family fixed effects.
\end{abstract}

JEL: D14, E21, G10.

Keywords: Household Finance. Intergenerational Mobility. Credit Constraints. Inequality.

We thank Joanna Hsu and audiences at the University of Illinois-Chicago and the Boulder Summer Conference on Consumer Financial Decision Making for their generous comments. Helen Irvin, David Min, and Peter Debbaut provided excellent research assistance. The views expressed here are those of the authors and do not necessarily reflect those of the Federal Reserve Bank of San Francisco, the Federal Reserve System, or any other institution with which the authors are affiliated. 


\section{Introduction}

Economists have long been interested in intergenerational economic mobility. A large, active area of research documents persistent intergenerational linkages in income (e.g., Solon, 1992; Chadwick and Solon, 2002), wealth (Charles and Hurst, 2003), and consumption (Waldkirch, Ng, and Cox, 2004). ${ }^{1}$ Economists have theorized that credit markets might be an important mechanism driving intergenerational mobility (Grawe and Mulligan, 2002). However, the intergenerational linkages in household credit have not been explored. Understanding the nature of such linkages and the factors that influence them can advance our understanding of intergenerational economic mobility and, more broadly, income inequality. ${ }^{2}$ Moreover, in the post-financial crisis world, intergenerational linkages in credit are important in and of themselves due to the rapid rise of the financial technology and a growing emphasis on financial literacy. ${ }^{3}$

We take a new approach to studying intergenerational economic linkages by exploiting the rich administrative panel data on individual credit records from the Federal Reserve Bank of New York Consumer Credit Panel/Equifax (CCP). To our knowledge, ours is the first study to explore intergenerational linkages in credit. Using household identifiers available in the CCP, we link individuals' credit records to the records of the adults (i.e., parents) in their household when the individuals were 18 or 19 years old, the earliest age at which an individual's information enters the credit report data. We refer to the former individuals as "children" and use panel dimension of the data to follow children's credit outcomes - default behavior, homeownership, credit card behavior, and the credit risk score as measured by Equifax Risk Score (hereafter, risk score) - for ten years. ${ }^{4}$ The intergenerational linkage is the slope of the linear relationship between the child's future credit outcome (up to the age of 29) and the parents' credit characteristics (the incidence of serious default, the degree of credit constraints, or risk score) at the time when the child was 18 or 19 years old and lived in the household with the parents.

\footnotetext{
${ }^{1}$ See reviews by Solon (1999) and Black and Devereux (2011) and the references therein.

${ }^{2}$ The rise in income inequality over the last decades and considerable body of research to understand it have recently placed a spotlight on understanding the role of the family (De Nardi and Fella, 2016).

${ }^{3}$ Chishti and Barberis (2016) describe a world in which financial literacy tests are obligatory for participation in the financial transactions.

${ }^{4}$ The data span allows us to study child credit outcomes up to the time when the children are 29 years old.
} 
We document several novel results. We first document economically and statistically significant linkages between children's future credit outcomes and their parents' credit risk scores, default, and credit constraints. Children of parents with high credit scores, low levels of credit utilization, and no serious defaults are less likely to default, have higher credit scores, are more likely to become homeowners in their 20s, and are more likely to have credit cards. Controlling for the household's location (zip code) weakens the relationships only slightly, suggesting the linkages are not merely caused by access to local amenities such as schools or the affluence of the child's peers. Rather, there exists a correlation between parents' and children's credit market outcomes in excess of the effect of neighborhood. Furthermore, the relationships persist into ages 25 to 29 .

The magnitudes of the effects are economically large. For example, after controlling for zip code and cohort fixed effects, a one standard deviation increase in parental credit risk score is associated with a 35 percent reduction in the child's likelihood of bankruptcy, a 49 percent decrease in the child's likelihood of other serious default, and a 6 percent increase in the child's credit score by the time the child is 25 years old. It is also associated with a 12 percent increase in the likelihood of becoming a homeowner by age 25 and a 23 percent increase by age 29. Conversely, a one standard deviation increase in the extent to which parents are credit constrained is associated with an 8 percent reduction in the likelihood of a child becoming a homeowner by age 25 and a 14 percent reduction by age 29. We also find that weaker parental credit conditions are positively associated with the child having student debt, with the relationship being much stronger in higher quintiles of parental income distribution. ${ }^{5}$

In the second part of the study, we examine what local factors are correlated with the strength of the linkages. We consider a broad range of local characteristics correlated with income mobility as well as the income mobility measures of Chetty, Hendren, Kline, and Saez (2014). Overall, we find that the linkages are stronger in cities with lower levels of income mobility suggesting that some of the same factors that drive intergenerational linkages in household credit also drive income mobility. The linkages, however, are not consistently stronger in cities with more income inequality as measured by the Gini coefficient.

${ }^{5}$ The data, however, do not contain information on college attendance. 
In the third part of the study, we turn to the question of what policies can affect the strength of the intergenerational linkages in household credit. The identification strategy exploits state-level differences over time in economic, financial, and quantitative literacy programs that Brown, Grigsby, van der Klaauw, Wen, and Zafar (2016) and Urban and Schmeiser (2015) document. We also examine whether the quality of public schooling affects the linkages, as high-quality public schooling is often perceived as the main equalizer of opportunity for children. Among the four policy interventions that we study (financial literacy, economic education, mathematics education, and school spending per pupil), we find that higher economic education requirements is the only policy that slightly weakens the intergenerational linkages in household credit.

Finally, we study the factors that drive the intergenerational linkages in household credit. First and most importantly, we find that the linkages persist and are only slightly weaker even when controlling for parental income. Second, we examine whether the correlations can be explained by family heterogeneity, i.e., underlying factors that drive both the credit attributes of parents and the future credit outcomes of their children. The linkages, alternatively, may arise because the credit conditions parents experience directly affect their children's outcomes because more creditconstrained parents have less resources available to invest in their children.

To control for family fixed effects, we construct a sample of siblings that gives us observations on more than one child-parent pair from within the same family. We then exploit between-sibling variation in their parents' credit characteristics, measured when each sibling is 19 . How the future credit outcomes vary across siblings as parental credit conditions change informs us as to whether the linkages arise because credit conditions that the parents experience directly affect their children's outcomes.

In the sample of siblings, we cannot reject the hypothesis that the linkages are due to family fixed effects. These results do not necessarily imply that parental credit constraints do not matter, because the sibling results are picking up the effect of changes in parental credit conditions late in childhood. ${ }^{6}$ Rather, the siblings results show that there are parental endowments beyond current financial resources that are important for child outcomes.

\footnotetext{
${ }^{6}$ For example, Lochner and Monge-Naranjo (2012) argue that credit constraints matter most early in life.
} 
In summary, we find economically important intergenerational linkages between children's future credit outcomes and their parent's credit attributes when the children are in their late teens. The linkages persists after controlling for zip code fixed effects and parental income, and are little affected by differential state-level educational policies. An initial investigation from a sample of siblings suggests that these linkages might be due, to a large extent, to family heterogeneity. Ours is the first study that documents intergenerational linkages in household credit. More research is needed to understand the factors behind the linkages. Similarly to numerous papers on intergenerational economic mobility, in this study we focus on parental credit attributes during a particular period of children's life (late adolescence). ${ }^{7}$ As more data become available, future research can look into the factors that cause some households to fare better in credit markets than others. Specifically, there is a need for models that illustrate how household characteristics that persist across generations manifest themselves in credit market outcomes, such as default and homeownership.

\subsection{Related Literature}

To our knowledge, ours is the first study of intergenerational linkages in household credit. The study is related to the extensive literature on intergenerational mobility in income, wealth, and consumption. ${ }^{8}$ Similarly to our conclusions, the existing evidence points towards a large unexplained component - family heterogeneity. In a seminal review, referring to intergenerational mobility of income, Solon (1999) concludes “[...] A comparison of sibling and intergenerational correlations suggests that much, perhaps most, of the intergenerational influence on earnings is unrelated to parental income. Where it does come from remains a fascinating and important puzzle for future research.”

Similarly, Charles and Hurst (2003) use the Panel Survey of Income Dynamics (PSID) to document intergenerational linkages in wealth and find that more than a third of the relationship

\footnotetext{
${ }^{7}$ For example, Lovenheim (2011) studies the effect of short-run housing wealth changes to identify the effect of housing wealth on college attendance. Cooper and Luengo-Prado (2015) examine whether rising house prices immediately prior to children entering college have an impact on their earnings as adults.

${ }^{8}$ See, among others, Solon (1992), Chadwick and Solon (2002), Aaronson and Mazumder (2008), Lee and Solon (2009), Corak (2013), Chetty, Hendren, Kline, and Saez (2014), Chetty, Hendren, Kline, Saez, and Turner (2014), Dahl, Kostol, and Mogstad (2014), Olivetti and Paserman (2015), and Olivetti, Paserman, and Salisbury (2015).
} 
between parental and child wealth remains unexplained after controlling for income, propensity to own assets, education, gifts, and expected bequests. Even after controlling for income, there are similarities in the types of assets that children and parents hold, a finding that they attribute to similarities in risk preferences. Fagereng, Guiso, Malacrino, and Pistaferri (2016) use Norwegian data to document heterogeneity and persistence in returns to wealth and find that the permanent component of the return to wealth is correlated across generations. Waldkirch, Ng, and Cox (2004) use data from the PSID to report that there are similarities in familial consumption patterns even after controlling for parental income. Charles, Danziger, Li, and Schoeni (2014) similarly find that intergenerational linkages in consumption patterns persist after controlling for intergenerational linkages in income.

The findings above suggest that children may have similar preferences to their parents. Dohmen, Falk, Huffman, and Sunde (2012) and Zumbuehl, Dohmen, and Pfann (2013) use German survey data to test more directly for intergenerational linkages in preferences. They find that attitudes toward risk are linked across generations. Cesarini, Dawes, Johannesson, Lichtenstein, and Wallace (2009), Barnea, Cronqvist, and Siegel (2010), and Cesarini, Johannesson, Lichtenstein, Sandewall, and Wallace (2010) use data on twins to conclude that genetics constitute a substantial component of risk preferences. Kuhnen and Chiao (2009) and Zhong, Israel, Xue, Ebstein, and Chew (2009) link risk-taking behavior with particular genes. Such similarity in preferences will manifest itself in household fixed effects and suggests a reason why we observe intergenerational linkages in credit even if changes to parental credit conditions do not affect children.

Our work is also related to a literature in labor economics that studies intergenerational linkages in labor market outcomes or transmission of human capital. ${ }^{9}$ For example, Keane and Wolpin (2001) study whether the documented positive relationship between parents' and children's higher education is causal (i.e., more educated parents, due to their own preferences for more educated children and/or higher wealth, may invest more heavily in their children's human capital) or due

\footnotetext{
${ }^{9}$ For example, Oreopolous, Page, and Stevens (2008) find that children of parents displaced from a job during plant closures have lower long-run earnings. Hilger (2016) finds that layoffs dramatically reduce family income but only slightly reduce college enrollment, college quality and early career earnings, consistent with a weak estimated propensity to spend on college out of marginal parental income. More generally, Vosters and Nybom (forthcoming) find intergenerational persistence in socioeconomic status rather than merely income, wealth, or education.
} 
to family heterogeneity (i.e., due to the heritability of traits, whereby children of more educated parents may inherit the abilities, personalities, and preferences that led to the higher educational achievement of their parents). Keane and Wolpin find that while some of the intergenerational correlation in schooling can be attributed to the larger college attendance contingent transfers made by more educated parents, essentially none of the correlation can be attributed to credit market constraints (i.e., the relaxation of borrowing constraints induces students to work less while in college, but it does little to affect attendance decisions).

Parents may also transmit human capital to their children in excess of what may manifest itself in the labor market. In particular, parents may transmit financial literacy. Lusardi, Mitchell, and Curto (2010) use the National Longitudinal Survey of Youth (NLSY) to conclude that financial literacy among youth is generally low. Moreover, they report that youth financial literacy is strongly associated with family financial sophistication.

The remainder of the paper proceeds as follows. Section 2 describes the framework for measuring the intergenerational linkages in household credit and the data. Section 3 documents our benchmark measurement of linkages in household credit markets. Section 4 explores environmental factors that affect the strength of the intergenerational linkages. Section 5 studies the effect of educational policy interventions on the linkages. Section 6 re-estimates the benchmark specifications with controls for parental income, and examines the mechanism behind the intergenerational linkages using a sample of siblings. Finally, Section 7 concludes.

\section{Framework for Measuring Intergenerational Linkages in Household Credit}

\subsection{New York Federal Reserve Bank Consumer Credit Panel/Equifax Data}

The data are from the New York Federal Reserve Bank Consumer Credit Panel/Equifax (CCP). The CCP is an individual-level panel dataset that contains detailed records of individual debt and borrowing on a quarterly basis from the first quarter of 1999 to the most recent quarter. The CCP is a 5 percent random sample of all U.S. consumers with a credit record. These individuals constitute the primary sample. In addition, the CCP has information about individuals who reside at the same address as individuals in the primary sample. Using this information, we link individual 
records to a household and then use individuals' ages to identify children's and parents' records as described below. ${ }^{10}$

The advantage of the CCP relative to survey data (e.g., PSID, Health and Retirement Study, NLSY) is its sample size and accuracy. The data in the study cover the period from the first quarter of 1999 to the fourth quarter of 2013. The resulting dataset on children contains over 300,000 individual records that we follow for a full decade starting in 1999-2003 and even more individual records that we follow for five years.

The CCP data contain detailed credit records data but no information on income. In Sections 3 and 6, we supplement the analysis with data from Equifax Credit Risk Insight ${ }^{\mathrm{TM}}$ Servicing McDash (CRISM) which is a subset of the CCP data matched to the mortgage-level McDash servicing data. The CRISM dataset contains the income variable, Personal Income Model (PIM), which is ameasure from a proprietary algorithm that exploits a large national sample of employer-provided incomes to predict consumer incomes using credit bureau attributes. The CRISM data are available starting in 2005.

\subsection{Construction of Intergenerational Records}

To link the data records of children and parents, we combine individual records that correspond to the same mailing address into household records. The earliest age of the individuals included in the CCP is generally 18. In the paper, we refer to the individuals for whom we have records at age 18 or 19 as children. An individual who resides in a household with a 19-year-old child and is 34 years or older is considered a parent (i.e., an adult in the household). The adult might not be a genetic parent of the child. However, the analysis in the paper is concerned with the transmission of credit market behavior within the household in which the child grows up rather than solely genetic transmission (for a similar focus, see, for example, Solon, 1992). ${ }^{11,12}$ Having identified children and their parents from the household identifiers at the time when children are 18 or 19

\footnotetext{
${ }^{10}$ Lee and van der Klaauw (2010) provides an excellent description of the CCP data and contains additional details on the CCP.

${ }^{11}$ To decrease the probability of capturing some nontraditional living arrangements (for example, military bases), we restrict our analysis to the individuals who at the age of 19 live in households with at most two adults. We also drop households with more than 10 members.

${ }^{12}$ Dettling and Hsu (2014) use the household dimension of the CCP data to study debt and parental coresidence among young adults.
} 
years old, we follow the individual records over time even when children and their parents no longer reside in the same household. We present results from the sample of the individuals whom we identify as children at 19 years old. ${ }^{13}$ While our identification limit us to children that live with their parents at age 19, a high fraction of young adults live with their parents at age $19 .{ }^{14}$ Our data also do not contain information on "unbanked" individuals.

\subsection{Measurement Framework for Intergenerational Linkages}

We define the intergenerational linkages in household credit as the slope of the linear relationship between an individual's (i.e., child's) credit outcomes and the individual's parents' credit characteristics at the time when the individual was 19 years old and lived in the same household with the parents

We focus on measuring the children's credit outcomes at two different time horizons: (1) a shortterm horizon, which covers the first five years after we identify an individual as a child in our sample, i.e., the period when the children are 19 to 24 years old; and (2) a long-term horizon, which covers the second five-year period after we identify an individual as a child in our sample, i.e., the period during which children are between 25 and 29 years old. ${ }^{15}$ Since the data in the study cover the first quarter of 1999 to the fourth quarter of 2013, we can identify five cohorts of children cohorts who are 19 in 1999, 2000, 2001, 2002, and 2003 - whom we can follow for the full 10 years and thus construct both the short- and long-term horizon outcomes. We use data from the fourth quarter of each year.

We consider the following children's credit outcomes: default patterns (delinquencies and serious default), credit risk score (Equifax Risk Score), homeownership status, and having a credit card. We define indicators of default, homeownership, or having a credit card using the information from the years between $t_{0}$ and $t_{0}+5$ for short horizon outcomes and from the years between $t_{0}+6$

\footnotetext{
${ }^{13}$ In unreported analyses, instead of 19-year-olds, we use 18-year-olds (with parents being 33 or over). The results using 18-year-olds are very similar to those with 19-year-olds. The results from this sample are available from the authors upon request.

${ }^{14}$ In the 2000 US Census, $57 \%$ of men and $47 \%$ of women aged $18-24$ lived with their parents while. In the 2010 Census, $57 \%$ of men and $48 \%$ of women aged $18-24$ lived with their parents.

${ }^{15}$ In the appendix Table A8, we consider child outcomes over a range of possible horizons since age 19.
} 
and $t_{0}+10$ for long horizon outcomes. For the credit risk score, we consider the average risk score over the respective horizon as well as the end-of-horizon risk score.

We define parents' credit attributes using information from the year when the child is 19 years old $\left(t_{0}\right)$. For parents, we create variables that summarize whether a parent has a default and its severity (e.g., bankruptcy, foreclosure, or delinquency), the extent to which the parent is credit-constrained, and the parents' average credit score.

In the benchmark analysis, we estimate the following relationship

$$
\mathrm{C}_{i a T}=\alpha+\beta \mathrm{P}_{i a_{0}}+\delta \mathrm{A}_{i a_{0}}+\mathrm{D}_{t_{0}}+\mathrm{D}_{a}+\mathrm{D}_{a t_{0}}+\varepsilon_{i a T}
$$

where $\mathrm{C}_{i a T}$ is the outcome of child $i$ over horizon $\mathrm{T}$ ( $\mathrm{T}$ is between $t_{0}$ and $t_{0}+5$ for the short horizon and between $t_{0}+6$ and $t_{0}+10$ for the long horizon), $P_{i t_{0}}$ is the outcome of parents of child $i$ in year $\mathrm{t}_{0}, \mathrm{~A}_{\text {iat }}$ is the age of the parents of child $i$ in year $\mathrm{t}_{0}, D_{t_{0}}$ is the cohort effect of children who are 19 in year $\mathrm{t}_{0}, D_{a}$ is the location-specific effect of location $a$ where the child resides when she is 19 , and $D_{a t_{0}}$ is the cohort- and location-specific effect. In the estimation below, we also allow the linear relationship described in (1) to differ by quartile of the distribution of the parents attribute for continuous attributes.

The child's credit outcomes we analyze are indicators of bankruptcy, serious default, and delinquency in any of the years during the short- or long-term horizon, an indicator of homeownership, an indicator for having a credit card, and, finally, the average risk score over the horizon and the end-of-the-horizon risk score. ${ }^{16}$ We use three alternative variables to summarize the parents' credit attributes at the time their child is 19 years old. First, we consider a binary variable, $P_{i a t_{0}}^{D}$, that takes value 1 if any parent has a serious default at $t_{0}$, where serious default is defined when a parent has a 90-day or greater delinquency, a bankruptcy, or a foreclosure. The second measure, $P_{\text {iat }_{0}}^{C}$, is the credit balance as a percentage of credit limit available for use at time

\footnotetext{
${ }^{16}$ Appendix A contains a detailed description of the variables.
} 
$t_{0}$. It captures the extent to which a parent may be able to borrow to improve their children's outcomes. Finally, $P_{i a_{0}}^{R}$, is the parents' risk score (the average of the scores if there are two parents).

\subsection{Summary Statistics}

Table 1 shows the summary statistics of the parental variables when the children are 19 years old. Panel A of Table 1 shows the summary statistics for the parents for the sample of 19-year-olds that we can follow until age 24. Panel B shows the statistics for the parents of the 19-year-olds that we can follow until age 29. If a child has two parents in the CCP, the summary statistics in Table 1 are calculated using both observations; see the appendix for details. In general, the samples in Panel A and B are very similar.

For comparison, the last column of Table 1 presents analogous statistics for adults 34 years or older who have at least one child 18 years or older in the 1998 through 2010 waves of the Survey of Consumer Finances (SCF). The parents in the CCP sample look broadly similar to those in the SCF. The CCP parents' homeownership rate is slightly lower than the homeownership rate in the SCF (55 percent vs. 65 percent), largely because in our data we define homeownership as having a mortgage. In both samples, 8.0 percent of parents have experienced a bankruptcy in the last 10 years (the longest time a bankruptcy can be retained on a credit record). The average age of parents in the CCP is 48 while it is 45 in the SCF. The most substantial difference is that only 22 percent of parents in the CCP sample are single parents, while 30 percent of parents in the SCF are single parents.

Table 2 presents key statistics for the children in our sample at ages 24 and 29. Panel A presents these statistics for the sample of children that we follow to age 24, i.e., those children who turn 19 in 1999 through 2003. In this sample, 34 percent experience a serious default sometime between ages 19 and 24, 10 percent become homeowners by age 24 and 84 percent have a credit card at some point between ages 19 and $24 .{ }^{17}$ The average Equifax Risk Score at age 24 is 636. Panel B presents the same statistics for individuals who are 25 to 29 years old, that is, those individuals

\footnotetext{
${ }^{17}$ The rate of serious default in our sample is higher than the delinquency rate because we use only data from quarter four of the year. Serious default is akin to a stock variable while delinquency is a flow variable such that an individual could enter serious default in Q2 and remain there in Q4 without our ever having observed a delinquency. See Debbaut, Ghent, and Kudlyak (2016) for additional discussion of this feature of the CCP data.
} 
who turn 19 sometime between 1999 and 2003 and whom we can follow to age 29 - the long horizon sample. ${ }^{18}$ The long horizon sample has fewer observations than the short horizon sample because fewer individuals can be followed for 10 years than can be followed for five years. ${ }^{19}$

Although the SCF has too few observations of any particular age to compare to our young individuals, we can get some sense of the representativeness of the children in our sample by comparing all individuals aged 24 and aged 29 in the CCP to those in our sample of children. Table 3 presents these comparisons. The children in our sample are more likely to have a credit card and be homeowners than all young adults in the CCP. However, the individuals in our sample have similar credit scores, delinquency rates, and rates of serious default to the population as a whole.

\section{Intergenerational Linkages in Household Credit}

This section documents key empirical facts about intergenerational linkages in household credit. We first measure the strength of the linkage between parental and child credit outcomes controlling only for cohort effects without conditioning on geographic location. We then analyze how much of the linkage across generations is explained by the household's geographic location at $t_{0}$ versus differences in parental characteristics within the location and variation over time in the labor market opportunities available to individuals in different locations. Finally, to absorb differential changes in macroeconomic conditions over time, we estimate an equation with state-cohort fixed effects.

Tables 4 through 6 show the relationship between children's outcomes and parental credit attributes - parental default, the extent of parental credit constraints, and parental credit score, respectively. For each child outcome, we estimate three different specifications. The first row for

\footnotetext{
${ }^{18}$ Unlike the rest of the variables, the following variables - an indicator of whether the child left the parents' home, the age at which she left home, the age when she got her first card, and the age at which she bought her first home - are defined over the entire 10 years in the long horizon sample rather than just ages 25-29. ${ }^{19}$ Also, the individuals in the long horizon sample are not strictly a subsample of the individuals in the short horizon sample or vice versa. This is because, to be included in the short or long horizon sample we require the individual to have a credit record at the end of the horizon (at 24 years old for the short horizon and at 29 years old for the long horizon) and at age 19. In the appendix Table A1 presents summary statistics for an alternative definition of the short horizon sample in which the short horizon sample is a subsample of the long horizon sample.
} 
each outcome shows the coefficients from the specification with cohort effects. The second row shows the coefficients from the specification with cohort and zip code fixed effects. Finally, the third row shows the coefficients from the specification with cohort, zip code, and state-cohort fixed effects. Depending on the child's outcome, including zip code fixed effects decreases the magnitude of the coefficients on parental variables by 10 to 30 percent. The results using cohort, zip code, and state-cohort fixed effects are virtually identical to those with only cohort and zip code fixed effects. All the results in the tables are based on specifications in which the standard errors are clustered by state. Finally, Table 7 aids in the interpretation of the effects by providing a summary of the magnitude of the estimated effect in response to a one standard deviation increase in $P_{\text {iat }_{0}}^{C}$ and $P_{i a_{0}}^{R}$ for each of the child outcome variables from the regressions with zip code fixed effects presented in Tables 4 through 6. ${ }^{20}$

\subsection{Children's Default and Bankruptcy}

As can be seen in Tables 4 through 6, there exist strong intergenerational linkages between children's likelihood of default or bankruptcy and the parental credit attributes. The linkages are found between parental credit attributes and children's outcomes measured when children are 1924 years old and also children's outcomes measured at 25-29.

In particular, focusing on the results with zip code fixed effects, we observe that children of parents with stronger credit characteristics (i.e., those without a serious default, those less credit constrained, and those with higher credit scores) are less likely to experience a bankruptcy or other serious default and less likely to be delinquent. For delinquency and other serious default, the magnitude of the effect is slightly larger in the 19- to 24-year-old sample than in the 25- to 29year-old sample. For bankruptcy, the effect of parental credit is twice as large for 25- to 29-yearolds than for 19- to 24-year-olds in part because there are relatively few bankruptcies among those under the age of 25 (see Table 2).

\footnotetext{
${ }^{20}$ In Tables 4-6 we present the results from the regressions in which children's outcomes are measured at two horizons, i.e., when the children are 19-24 years old and when the children are 25-29 years old. In Table A8 in the appendix, we present results from the regressions estimated separately for each age between 20 and 29. All results carry through.
} 
The magnitudes of the intergenerational credit linkages are economically substantial. For example, children of parents with a serious default are 68 percent (1.3 percentage points) more likely to experience a bankruptcy by age 24 and 46 percent (2.4 percentage points) more likely to experience a bankruptcy between ages 25 and 29. A one standard deviation increase in $P_{i a_{0}}^{R}$ is associated with a 24-35 percent decrease in the risk of bankruptcy, a 36-49 percent decrease in the risk of other serious default, and a 23-36 percent decrease in the risk of delinquency for the child (see Table 6).

\subsection{Children's Homeownership and Credit Cards}

Children's participation in credit markets is also correlated with parental credit attributes. Children of parents with good credit characteristics are more likely to become homeowners or have a credit card early in life. For example, a one standard deviation increase in $P_{\text {iat }_{0}}^{C}$ is associated with an 8 percent decrease in the probability of the child becoming a homeowner by the age of 24 and a 14 percent decrease in the probability that the child becomes a homeowner by age 29. Similarly, a one standard deviation increase in $P_{\text {iat }_{0}}^{R}$ is linked to a 12 percent increase in the probability that a child is a homeowner by age 24 and a 23 percent increase by age 29. In the regressions for homeownership presented in Tables 4 through 6, the coefficients on parental age are all negative and statistically significant indicating that children of older parents are less likely to become homeowners.

\subsection{Children's Credit Risk Scores}

Children of parents with a serious default have Equifax Risk Score 51 points lower at age 24 and 46 points lower at age 29 than those of parents without default. A one standard deviation increase in the extent to which parents are credit constrained is associated with child risk score 4 percent lower at age 24 and a 3 percent lower at age 29. Similarly, a one standard deviation increase in the parental risk score is associated with child risk score that is 6 percent higher at age 24 and 5 percent higher at age $29 .{ }^{21}$

\footnotetext{
${ }^{21}$ We also estimate the relationship between $P_{i a t_{0}}^{C}$ and children's risk scores as well as between $P_{\text {iat }_{0}}^{R}$ and children's risk scores using quantile regression. The relationships are similar at the $25^{\text {th }}, 50^{\text {th }}$, and $75^{\text {th }}$ percentiles. These results are available from the authors upon request.
} 
One might be concerned that the documented linkages in household credit could mechanically arise due to children and parents sharing cosigned credit cards. We thus re-estimate the benchmark specification in equation (1) adding an indicator for whether a child has a cosigned account in retail trade or credit card and the interaction of this indicator with the parental credit variable. We find that the documented intergenerational linkages in credit are very similar to the ones estimated in our benchmark specification. Consequently, the benchmark results on the linkages are not driven by the joint accounts. ${ }^{22}$

\subsection{Children's Student Debt}

A key outcome for young adults is whether they attend college and, if they do, whether they accumulate debt that has consequences later in life. Our data do not indicate whether the individual attends (or attended) a college; however, it contains information on whether the individual has a student loan. If all individuals who attended college did so using a student loan, we could use our data to measure the extent to which parental credit characteristics correlate with college attendance. However, less than $40 \%$ of youth that attend college have student debt (Avery and Turner, 2012). As such, no student debt indicates one of two very different things: Either 1) the individual does not attend college, or 2) the individual attends college but is fortunate enough to not have to take on student debt to do so. To understand the relationship between parental credit characteristics and children's student debt, it is therefore important to condition on additional information.

We use information about parental income. Our logic is that the presence of student debt has a more homogeneous meaning for kids within a parental income group. For example, existing literature documents that children from higher income groups are much more likely to attend college. Carneiro and Heckman (2002) report that, in 1998, 80\% of male 18-24 year-old high school graduates from parents in the top quartile of the income distribution attended college while only 50\% of those from the bottom quartile attended college. Lochner and Monge-Naranjo (2011) also report that, within all AFQT score quartiles, children from higher income backgrounds are more likely to attend college. ${ }^{23}$ Consequently, we hypothesize that, for children of higher income

\footnotetext{
${ }^{22}$ These results are in Tables A2-A4.

${ }^{23}$ Since high school completion rates and AFQT scores increase with parental income (Belley and Lochner, 2011) and our data do not condition on high school completion or AFQT rates, we expect the relationship
} 
parents, the lack of a student loan is not a good predictor that the individual does (or did) not attend college. However, the presence of a student loan in the records of children of higher income parents is likely to indicate that the individual is forced to borrow to go to college instead of getting parental cash transfers.

We estimate our benchmark regressions by parental income quintile. For this exercise, we use a subsample of the CCP that has predicted income via CRISM as described in Section 2. Since the CRISM data are available only starting in 2005, we can follow children for only 5 rather than 10 years as in the benchmark sample.

Table 8 shows that weaker parental credit conditions are associated with a greater likelihood of the child having student debt by age 24 for all income quintiles. The relationship is much stronger as parental income increases. The relationship is highly statistically significantly for all five quintiles in the regression on parental credit constraints. That is, the more credit constrained the parents are, the more likely the children have a student loan. The estimates from the regression on parental default and parental credit score are qualitatively similar but not statistically significant for the lowest parental income quintile.

\section{Intergenerational Linkages in Household Credit and Local Characteristics}

In this section, we use the household's location information at the time the child is 19 years old to examine what local area characteristics are correlated with the strength of the intergenerational linkages.

\subsection{Local Income Levels, Income Inequality, and Racial Composition}

To estimate the role of the local area characteristics in the estimated intergenerational linkages, we estimate the following specification:

$$
\mathrm{C}_{i a T}=\alpha+\beta \mathrm{P}_{i a_{0}}+\gamma \mathrm{P}_{i a_{0}} L_{a}+\delta A_{i a t_{0}}+D_{t_{0}}+D_{a}+D_{a t_{0}}+\varepsilon_{i a T}
$$

to be even stronger in our data than the one estimated in the conditional data reported by Carneiro and Heckman (2002) and Lochner and Monge-Naranjo (2011). 
where $\mathrm{L}_{a}$ is the characteristic of area ${ }_{a}$ in year $t_{0}$ and $\mathrm{P}_{\text {iat }} \mathrm{L}_{a}$ is the interaction term between the area characteristic and the parental credit attribute.

Tables 9 and 10 contain estimates of the benchmark regressions with the local characteristic interacted with the extent of parental credit constraints and parental risk score, respectively. Following Chetty, Hendren, Kline, and Saez (2014), we consider the following area characteristics: per capita household income for working-age adults in the county, percent of middle class in the county (i.e., the fraction of parents in the county who have family incomes between the $25^{\text {th }}$ and $75^{\text {th }}$ percentiles of the national parent income distribution), county Gini coefficient, county-level income segregation, and the fraction of black residents in the county. ${ }^{24}$

For all local characteristics, we find that the coefficient on the parental credit attribute remains economically and statistically significant. In addition, the coefficients on the interaction terms between local characteristics and parental credit attributes are statistically significant. In locations with higher income, we find stronger intergenerational linkages for children's delinquency and risk score but weaker intergenerational linkages for homeownership and the presence of a credit card.

Intergenerational credit linkages are generally weaker in cities with higher inequality as measured by the Gini coefficient. They are also often weaker in cities with high income segregation. The coefficient on the interaction on the percent of middle class is often statistically insignificant but sometimes also indicates that the linkages are stronger in cities with a larger middle class, consistent with our results for the Gini coefficient. Overall, the linkages are not much stronger in cities in which a higher share of the population is black. The only case in which the interaction term between the percent of the population that is black and the parental credit attribute is consistently statistically significant is with parent risk score in the regression for child delinquency.

\subsection{Intergenerational Linkages in Household Credit and Income Mobility}

Finally, we examine the extent to which intergenerational linkages in household credit are driven by factors that are also associated with intergenerational income mobility. We use the MSA-level

\footnotetext{
${ }^{24}$ See Chetty, Hendren, Kline, and Saez (2014) for the calculation of county income segregation indicators.
} 
estimates of intergenerational income mobility from Chetty, Hendren, Kline, and Saez (2014), which are based on data from IRS tax records. We estimate the following specification

$$
\mathrm{C}_{i a T}=\alpha+\beta \mathrm{P}_{i a t_{0}}+\gamma \mathrm{P}_{i a_{0}} M_{a}+\mathrm{D}_{t_{0}}+\mathrm{D}_{a}+\varepsilon_{i a T}
$$

where $M_{a}$ is the income mobility measure in area ${ }_{a}$ and $\mathrm{P}_{\text {iat }_{0}} M_{a}$ is the interaction between the mobility measure and the parental attribute variable.

We estimate equation (3) for 381 MSAs and use the two measures of mobility provided by Chetty, Hendren, Kline, and Saez (2014). The first, relative mobility, is the difference in outcomes for children with the wealthiest parents from those for children with the poorest parents. A higher number indicates a greater correlation between parent and child outcomes and may thus perhaps be thought of as a measure of immobility. The second measure, absolute mobility, is the predicted rank for a child born to parents at the $25^{\text {th }}$ percentile and indicates a measure of upward mobility. The results of the estimation are contained in Tables 9 and 10 with the extent of parental credit constraints and parental risk score, respectively.

We find that intergenerational linkages in household credit are stronger in cities with lower intergenerational income mobility. While our analysis does not speak to the direction of the causality between intergenerational linkages in credit and income, the results suggest that common factors drive both. This conclusion is consistent with our finding in Section 6 that family heterogeneity drives the intergenerational linkages in household credit.

\section{Intergenerational Linkages in Household Credit and Educational Policies}

In this section, we examine whether local policy on financial education or, more generally, better school quality affect the strength of the intergenerational linkages.

\subsection{Financial Literacy, Economic Education, and Math Education}

To estimate the effect of educational policies on the strength of the intergenerational linkages in household credit, we augment equation (1) with interactions between parents' credit characteristics and state-level policy variables regarding financial education. Financial education may be 
associated with lower intergenerational linkages in household credit by reducing the influence of family background on financial decision-making.

The schooling curriculum regarding financial literacy, economic education or mathematical education varies by state and by year. We use the state-year classification for these three components from Brown, Grigsby, van der Klaauw, Wen, and Zafar (2016). ${ }^{25}$ For each state, Brown, Grigsby, van der Klaauw, Wen, and Zafar identify years in which each state changed requirements for each of the three components. Consequently, the educational policy varies across locations (states) as well as across time (for those states that experienced the policy change during the sample period). We estimate the following specification with different measures of local educational policy

$\mathrm{C}_{i a T}=\alpha+\beta \mathrm{P}_{i a_{0}}+\chi E_{a t_{0}}+\gamma \mathrm{P}_{i a_{0}} E_{a t_{0}}+\mathrm{D}_{t_{0}}+\mathrm{D}_{a}+\varepsilon_{i a T}$,

where, for economic and financial literacy, $E_{a_{0}}$ is a dummy variable for whether a financial literacy or economic education mandate was enacted or strengthened before the individual turned 18; for math, $E_{a t_{0}}$ takes values of 0,1 , or 2 for no reform, one reform, or two reforms.

Tables 11 and 12 contain the results of estimating educational policy equation (4) with two alternative parental credit attributes - the extent of parental credit constraints and parental risk score, respectively, separately for each educational policy.

If economic education improves decision-making in credit markets, the expected effect of the (level of) economic education on children's bankruptcy, delinquency, and serious default, ceteris paribus, is negative, while the expected effect on children's homeownership, likelihood of having a credit card, and risk score is positive. In addition, economic education might weaken intergenerational linkages in household credit by mitigating the influence of household endowments. That is, under the null hypothesis, the sign on the interaction term between the economic education measure and the parental credit attribute is opposite of the sign of the coefficient on the parental credit attribute variable.

\footnotetext{
${ }^{25}$ See Table 1 in Brown, Grigsby, van der Klaauw, Wen, and Zafar (2016).
} 
As Tables 11 and 12 show, the estimated coefficient on the economic education measure is small in magnitude and often not statistically significant for children credit outcomes except for endperiod children risk score, for which the coefficient is statistically significant and has an expected positive sign. However, since we cannot include state-year fixed effects in a regression that also includes a state-specific and time-varying measure of economic education in levels and cohort fixed effects, the coefficient on the economic education measure might capture state effects other than educational policy. We thus focus on the interaction between the educational policy variables and parental credit attributes.

In the regressions with child bankruptcy, delinquency, serious default, homeownership, and risk score, the interaction term and parental credit attribute variable have opposite signs. This suggests that a higher level of economic education is associated with weaker intergenerational linkages in household credit. The coefficient on the interaction term is close to zero and not statistically significant only in the regressions on the credit card indicator. Importantly, the inclusion of the interaction term of the economic education measure and a parental credit attribute in equation (1) leaves the coefficient on the parental credit attribute almost unchanged.

We next proceed to analyzing the effect of financial literacy. We estimate equation (4) using the financial literacy measure from Brown et al. (2016). As Tables 15 and 16 show, the estimated coefficient on the financial literacy measure is small in magnitude and often not statistically significant. As can be seen from Tables 11 and 12, the inclusion of the interaction terms between financial literacy and parental credit attributes in equation (1) leaves the coefficient on the parental credit attribute almost unchanged and the interaction term itself is rarely statistically significant. Consequently, it appears that the changes in the state-specific measures of financial literacy requirements do not affect intergenerational linkages in household credit.

Similarly, we find no statistically significant effect of existing measures of mathematical reform on intergenerational linkages in household credit. $^{26}$

\footnotetext{
${ }^{26}$ We also re-estimate educational policy equation (4) using alternative measures of financial and economic education across states. In particular, we use the state graduation requirement variables developed by Urban and Schmeiser (2015). However, the same conclusions carry through. These results are contained in Table A5 (for the extent of parents' being credit constrained) and Table A6 (for the parents' risk score).
} 


\subsection{School Quality}

Finally, we examine the effects of school quality on intergenerational linkages in credit. We use local tax rates as a proxy for the quality of inputs into public schooling. Because public schools in the United States are primarily funded by local taxes, areas with higher local taxes are likely to spend more on schooling. In particular, we estimate

$$
\mathrm{C}_{i a T}=\alpha+\beta \mathrm{P}_{i a_{0}}+\gamma \mathbf{P}_{i a_{0}} S_{a}+\mathbf{D}_{t_{0}}+\mathbf{D}_{a}+\varepsilon_{i a T},
$$

where $S_{a}$ is the average total spending per pupil on K-12 education in student $i$ 's state of residence. The data on state-level spending per pupil is available from the U.S. Census Bureau tables "Public Elementary-Secondary Education Finance Data” for 2001-2012. We use the earliest year available, 2001-2002. As in estimating equations (3) and (4), the first order effect of $S_{a}$ is subsumed in the zip code fixed effects.

The results of the estimation are contained in Tables 11 and 12. In general, higher levels of school spending are associated with weaker transmission of parental credit characteristics on homeownership and participation in credit card markets. However, the effect of parental credit characteristics on delinquency and risk scores is actually stronger in states with higher spending per pupil. As such, high-quality schooling does not seem to level the playing field.

\section{What Drives the Intergenerational Linkages in Credit?}

Finally, in this section we examine the factors that drive the intergenerational linkages in credit. First, we study whether the documented linkages can be entirely explained by parental income. Second, we study the role of family heterogeneity in a sample of siblings.

\subsection{The Role of Parental Income}

We first examine whether the documented intergenerational linkages in credit are present even after controlling for income. To understand the relations between parental income and the intergenerational linkages in credit that we have documented, we use the data from CRISM, which 
is a subsample of the CCP that contains information on predicted individual income and is available from 2005-onwards.

First, we find that income and credit characteristics are closely related (Table 13). There is a monotonic relationship between predicted income and risk scores although there remains substantial individual heterogeneity around the means. Those in the lowest quintile of income have the lowest risk scores, averaging 624. The average risk score for those in the middle quintile of income is 738 while individuals in the top quintile of income average risk scores of 781.

We now assess to what extent the estimated intergenerational linkages in credit are capturing the role of income rather than credit characteristics per se. We re-estimate our benchmark regressions in the sample from CRISM, without and with the parental income variable. Table 14 presents the results from estimating equation (1) for various children's outcome on the parental credit score and parent income using the CRISM sample for the horizon $t_{0}+5$. We find that higher parental income is associated with a lower likelihood of bankruptcy, delinquency, and other serious default and a greater likelihood of having a credit card. Higher parental income is also associated with higher credit scores for children. Most importantly, including parental income only slightly weakens the intergenerational linkages in credit or, in the case of homeownership, actually strengthens the linkage. Adding a control for parental income to the regressions where we use parental credit constraints or parental default for measurement of intergenerational linkages in credit also has a negligible effect on the benchmark estimates of the linkages. ${ }^{27}$

\subsection{Family Heterogeneity: Evidence from Siblings}

The previous section documents that individuals whose parents are more credit-constrained at the time when individuals are in their late teens are more likely to be in default and have lower risk scores in the future. What factors drive such intergenerational linkages? There are a few potential mechanisms. One possibility is that the credit conditions experienced by the parents when the child is a teenager directly affect their children's outcome. Another possibility is that the correlations are entirely due to family heterogeneity, i.e., underlying factors that drive both the credit attributes

\footnotetext{
${ }^{27}$ These results are available from the authors upon request.
} 
of parents and the future credit outcomes of children. The two mechanisms are not mutually exclusive.

To better understand these alternatives, consider, for example, the case under which all individuals are homogeneous in terms of their preferences and endowments and are subject to similar shocks. Under this scenario, less credit-constrained parents have the means to invest more in their children's human capital or, more generally, are able to provide better insurance against shocks. As a result, children of less credit constrained parents are also less credit constrained, fare better when faced with negative shocks, and their measurable credit market outcomes are better - they have higher risk scores and lower default rates. Under such a scenario, the documented intergenerational linkages are caused by parental credit characteristics.

Alternatively, consider the scenario wherein there is no causal effect of parental credit on the children's credit market outcomes. Instead, households differ in their preferences and/or endowments such that measurable credit market characteristics - risk scores, default rates, delinquency rates, homeownership rates - differ systematically across households. That is, children of parents with high risk scores tend to also have higher risk score, children of less creditconstrained parents tend to be less-credit constrained, and children from households where parents default less tend to also default less. However, higher parent risk score does not contribute to higher children's risk score and parents being less credit-constrained does not directly cause less credit-constrained children. Instead, the linkage arises due to, for example, some common saving and consumption habits passed from generation to generation or some other common factor. Under such a scenario, the documented intergenerational linkages are a result of family heterogeneity rather than being caused by parental credit market behavior or opportunities. Similarly, parental disadvantages in early childhood may manifest themselves as worse parental credit characteristics at the time the child is age 19.

The identification of which of the two scenarios better describes the estimated intergenerational linkages requires observations on more than one child-parent pair from the same household with some variability in the measured parents' credit characteristics in the pairs from the same household. We obtain such observations by constructing a sample of siblings. Using the sample of siblings, we estimate the following specification 
$C_{i a T}-\bar{C}_{i a T}=\alpha+\beta\left(P_{i a t_{0}}-\bar{P}_{i a T}\right)+\delta\left(A_{i t_{0}}-\bar{A}_{i a T}\right)+D_{t_{0}}+D_{a}+D_{a t_{0}}+\varepsilon_{i a T}$,

where $\bar{C}_{i a T}$ is the average outcome of all children in the household that child $i$ is associated with at age 19, and $\bar{P}_{i a T}$ is the average outcome of the parents at the time the children in the household are 19 years old. All other variable definitions are as described after equation (1).

The specification in equation (7) controls for the family fixed effect. Thus, any correlation between the difference in child ${ }_{i}$ s outcome and the average outcome of all children in the household, $\left(C_{i a T}-\bar{C}_{i a T}\right)$, and $\left(P_{i a T}-\bar{P}_{i a T}\right)$ is the causal effect of the parental attribute on the child's outcome.

In our analysis, the parental characteristics are measured as transitory changes in parental credit conditions late in childhood. Since we can only see children in our data starting at the age 18-19, the identifying assumption in equation (7) is then that parental credit conditions have more influence on the child at age 19 than later in life. This is plausible as age 19 is a crucial age for educational investment relative to older years and older children are typically more financially independent from their parents. Another important consideration for identification in equation (7) is how much variability is in the data in parental credit characteristics across siblings. First, the siblings in our sibling sample are on average 2 years apart from one another. ${ }^{28}$ Second, in our data the mean range of a 2-year horizon within-an-individual "Parent Constrained" and "Parent Risk Score” variables are 0.26 and 26, respectively. That is, within a 2-year horizon, an individual's risk score varies by an average of 26 points.

Table 15 contains the results from estimating the intergenerational linkages in the sample of siblings with controls for household-level fixed effects. To construct the household-level fixed effect, we estimate the specifications with continuous parental variables only - parental risk score and the extent of parental credit constraints. Column 1 shows the estimates of equation (1) for the sample of siblings. We confirm that the benchmark results on intergenerational linkages described in Section 3 are present in the sample of siblings. Column 2 shows the results from estimating equation (2). When we control for family heterogeneity, the estimated coefficient on the parental

\footnotetext{
${ }^{28}$ Table A7 contains summary statistics on siblings age differences.
} 
credit attribute, either parental risk score or parental credit constraint, is close to zero and not statistically significant across all child credit outcomes that we consider.

Consequently, the estimates reject the existence of linkages beyond family fixed effects. That is, the results suggest that the documented intergenerational linkages in household credit cannot be attributed to a causal link between parental credit conditions when the child is a teenager and future children credit outcomes. The same conclusion holds in the regressions without controls for zip code fixed effects (these results available upon request).

Table 16 repeats our student loan analysis in the sample of siblings for which we have CRISM data on predicted parental income. Because of the small sample size, we include state rather than zip code fixed effects in these specifications. In the specification in which we include family fixed effects, we see once again that parental credit conditions at the time the child is age 19 are not generally statistically significant predictors of whether a child has a student loan by age 24 .

\section{Conclusions}

We document the existence and quantify the extent of intergenerational linkages in household credit - the slope of the linear relationship between children's future credit outcomes and their parents' credit risk scores, default, and the extent of credit constraints at the time when the children are in their late teens. The linkages persist even after controlling for zip code fixed effects, and more importantly, parental income. Using U.S. state variation in educational policies, we find that educational policy has a limited influence on the strength of the linkages.

The results from a sample of siblings suggest that these linkages are to a large extent a result of family heterogeneity rather than parental credit market conditions when the child is a teenager directly affecting the credit outcomes of children as adults. The results are encouraging as they indicate that credit market frictions for parents are not so severe that transitory shocks in their children's late adolescence affect their children's future outcomes. Rather, the effects parents have on their children's outcomes arise due to, for example, (1) intergenerational transmission of preferences, or (2) disadvantages that parents face early in their children's lives that are likely correlated with parental credit market conditions later in life. These disadvantages likely affect 
kids' credit market conditions later in life consistent with the effect of parental income early in children’s lives on health outcomes (see Case, Lubotsky, and Paxson, 2002).

We also find that financial and economic literacy policies are improving credit market outcomes through some channel other than mitigation of the influence of family endowments. Our results indicate that any disadvantages children face from family endowments that manifest themselves in adverse credit market outcomes might be hard to overcome with conventional educational policies. Our work is the first study to document the intergenerational linkages in credit. In light of economically large and statistically significant documented linkages, our work invites further studies of the sources of the linkages. 


\section{References}

Aaronson, Daniel, and Bhashkar Mazumder. 2008. Intergenerational Economic Mobility in the US: 1940 to 2000. Journal of Human Resources 43(1): 139-172.

Avery, Christopher and Sarah Turner. 2012. Student Loans: Do College Students Borrow Too Much - Or Not Enough? Journal of Economic Perspectives 26(1): 165-92.

Barnea, Amir, Henrik Cronqvist, and Stephan Siegel. 2010. Nature or Nurture: What Determines Investor Behavior? Journal of Financial Economics 98: 583-604.

Belley, Philippe and Lance Lochner. 2007. The Changing Role of Family Income and Ability in Determining Educational Achievement. Journal of Human Capital 1(1): 37-89.

Black, Sandra E., and Paul J. Devereux. 2011. Recent Developments in Intergenerational Mobility. In O. Ashenfelter and D. Card, eds., Handbook of Labor Economics, Vol. 4, Elsevier, Chapter 16: 1487-1541.

Brown, Meta, John Grigsby, Wilbert van der Klaauw, Jaya Wen, and Basit Zafar. 2016. Financial Education and the Debt Behavior of the Young. Review of Financial Studies 29(9): 2490-2522.

Carneiro, Pedro and James J. Heckman. 2002. The Evidence on Credit Constraints in PostSecondary Schooling. The Economic Journal 112(October): 989-1018.

Case, Anne, Darren Lubotsky, and Christina Paxson. 2002. Economic Status and Health in Childhood: The Origins of the Gradient. American Economic Review 92(5): 1308-34.

Cesarini, David, Christopher T. Dawes, Magnus Johannesson, Paul Lichtenstein, and Bjorn Wallace. 2009. Genetic Variation in Preferences for Giving and Risk Taking. Quarterly Journal of Economics 124(2): 809-42.

Cesarini, David, Magnus Johannesson, Paul Lichtenstein, Orjan Sandewall, and Bjorn Wallace. 2010. Genetic Variation in Financial Decision-Making. Journal of Finance 65(5): 1725-54.

Chadwick, Laura and Gary Solon. 2002. Intergenerational Income Mobility Among Daughters. American Economic Review 92(1): 335-44.

Charles, Kerwin Kofi and Erik Hurst. 2003. The Correlation of Wealth across Generations. Journal of Political Economy 111(6): 1155-82.

Charles, Kerwin Kofi, Sheldon Danziger, Geng Li, and Robert Schoeni. 2014. The Intergenerational Correlation of Consumption Expenditures. American Economic Review 104(5): 136-40. 
Chetty, Raj, Nathaniel Hendren, Patrick Kline, and Emmanuel Saez. 2014. Where is the Land of Opportunity? The Geography of Intergenerational Mobility in the United States. Quarterly Journal of Economics 129(4): 1553-1623.

Chetty, Raj, Nathaniel Hendren, Patrick Kline, Emmanuel Saez, and Nicholas Turner. 2014. Is the United States Still a Land of Opportunity? Recent Trends in Intergenerational Mobility. American Economic Review Papers and Proceedings 104(5): 141-7.

Chishti, Susanne, and Janos Barberis. 2016. The FINTECH Book: The Financial Technology Handbook for Investors, Entrepreneurs and Visionaries, WILEY, 312 pp..

Cooper, Daniel, and Luengo-Prado, María José. 2015. House Price Growth when Children are Teenagers: A Path to Higher Intergenerational Achievement? Journal of Urban Economics, Vol. 86: 54-72.

Corak, Miles. 2013. Income Inequality, Equality of Opportunity, and Intergenerational Mobility. Journal of Economic Perspective 27(3): 79-102.

Dahl, Gordon, Andreas Ravndal Kostøl, and Magne Mogstad. 2014. Family Welfare Cultures. Quarterly Journal of Economics, Vol. 129(4): 1711-1752.

Debbaut, Peter, Andra C. Ghent, and Marianna Kudlyak. 2016. The Card Act and Young Borrowers: The Effects and the Affected. Journal of Money, Credit and Banking, Vol. 48(7): 14951513.

De Nardi, Mariacristina, and Giulio Fella. 2016. Saving and Wealth Inequality. University College London, Mimeo.

Dettling, Lisa J., and Joanne W. Hsu. 2014. Returning to the Nest: Debt and Parental Co-Residence Among Young Adults. Finance and Economics Discussion Series 2014-80. Board of Governors of the Federal Reserve System (U.S.).

Dohmen, Thomas, Armin Falk, David Huffman, and Uwe Sunde. 2012. The Intergenerational Transmission of Risk and Trust Attitudes. Review of Economic Studies 79: 645-77.

Fagereng, Andreas, Luigi Guiso, Davide Malacrino, and Luigi Pistaferri. 2016. Heterogeneity and Persistence in Returns to Wealth. Stanford University, Mimeo: http://web.stanford.edu/ pista/FGMP_submission_econometrica.pdf

Grawe, Nathan D., and Casey B. Mulligan. 2002. Economic Interpretations of Intergenerational Correlations. Journal of Economic Perspectives 16(3): 45-58.

Hilger, Nathaniel G. 2016. Parental Job Loss and Children's Long-Term Outcomes: Evidence from 7 Million Fathers' Layoffs. American Economic Journal: Applied Economics, Vol. 8(3): 247-283. 
Keane, Michael P., and Kenneth I. Wolpin. 2001. The Effect of Parental Transfers and Borrowing Constraints on Educational Attainment. International Economic Review, Vol. 42(4): 1051-1103.

Kuhnen, Camelia M. and Joan Y. Chiao. 2009. Genetic Determinants of Financial Risk Taking. PLOS ONE 4(2).

Lee, Chul-In and Gary Solon. 2009. Trends in Intergenerational Mobility. Review of Economics and Statistics 91(4): 766-72.

Lee, Donghoon and Wilbert van der Klaauw. 2010. An Introduction the FRBNY Consumer Credit Panel. Federal Reserve Bank of New York Staff Report No. 479.

Lochner, Lance J. and Alexander Monge-Naranjo. 2011. The Nature of Credit Constraints and Human Capital. American Economic Review 101: 2487-2529.

Lovenheim, Michael. 2011. The Effect of Liquid Housing Wealth on College Enrollment. Journal of Labor Economics, Vol. 29(4): 741 - 771.

Lusardi, Annamaria, Olivia S. Mitchell, and Vilsa Curto. 2010. Financial Literacy among the Young. Journal of Consumer Affairs 44(2): 358-80.

Olivetti, Claudia and M. Daniele Paserman. 2015. In the Name of the Son (and the Daughter): Intergenerational Mobility in the United States, 1850-1940. American Economic Review 105(8): 2695-724.

Olivetti, Claudia, M. Daniele Paserman, and Laura Salisbury. 2015. Three-generation Mobility in the United States, 1850-1940: The Role of Maternal and Paternal Grandparents. Working Paper, Boston University.

Oreopoulos, Philip, Marianne Page, and Ann Huff Stevens. 2008. The Intergenerational Effects of Worker Displacement. Journal of Labor Economics, Vol. 26(3): 455-483.

Solon, Gary. 1992. Intergenerational Mobility in the United States. American Economic Review 82(3): 393-408.

Solon, Gary. 1999. Intergenerational Mobility in the Labor Market. In O. Ashenfelter and D. Card, eds., Handbook of Labor Economics, Vol. 3, Elsevier: 1761-1800.

Urban, Carly and Maximilian Schmeiser. 2015. Historical Graduation Requirements in High School Curricula: Personal Finance and Economics. Manuscript, accessed at http://www.montana.edu/urban/research.html on 10/01/2015.

Vosters, Kelly N., and Martin Nybom. Forthcoming. Intergenerational Persistence in Latent Socioeconomic Status: Evidence from Sweden. The Journal of Labor Economics. 
Waldkirch, Andreas, Serena Ng, and Donald Cox. 2004. Intergenerational Linkages in Consumption Behavior. Journal of Human Resources 39(2): 355-81.

Zhong, Songfa, Salomon Israel, Hong Xue, Richard P. Ebstain, and Soo Hong Chew. 2009. Monoamine Oxidase A Gene (MAOA) Associated with Attitude Towards Longshot Risks. PLoS ONE 4(12).

Zumbuehl, Maria, Thomas Dohmen, and Gerard Pfann. 2013. Parental Investment and the Intergenerational Transmission of Economic Preferences and Attitudes. Working Paper, Maastricht University. 
Table 1: Parent Summary Statistics

\begin{tabular}{|c|c|c|c|c|c|c|c|c|c|}
\hline & Mean & Std. Dev. & Min & 25th \% & Median & 75th \% & Max & Obs. & $\begin{array}{l}\text { Mean } \\
\text { (SCF) }\end{array}$ \\
\hline \multicolumn{10}{|c|}{ Panel A: Parents of 19 year olds that can be followed to age 24} \\
\hline Parent Homeowner & 0.56 & 0.50 & 0 & 0 & 1 & 1 & 1 & 862,835 & 0.64 \\
\hline Parent Bankrupt & 0.08 & 0.27 & 0 & 0 & 0 & 0 & 1 & 862,835 & 0.08 \\
\hline Parent Serious Default & 0.18 & 0.38 & 0 & 0 & 0 & 0 & 1 & 862,835 & \\
\hline Parent Delinquency & 0.08 & 0.26 & 0 & 0 & 0 & 0 & 1 & 862,835 & \\
\hline Parent Credit Constrained & 0.33 & 0.32 & 0 & 0.04 & 0.20 & 0.58 & 1 & 693,210 & \\
\hline Parent Equifax Risk Score & 686.2 & 104.2 & 293 & 617 & 712 & 772 & 842 & 831,885 & \\
\hline Parent Age & 48.4 & 8.6 & 34 & 43 & 47 & 52 & 102 & 862,835 & 45.2 \\
\hline Parent Single & 0.20 & 0.40 & 0 & 0 & 0 & 0 & 1 & 862,835 & 0.30 \\
\hline Total Number in Household & 2.8 & 0.4 & 2 & 3 & 3 & 3 & 5 & 862,835 & 3.0 \\
\hline \multicolumn{10}{|c|}{ Panel B: Parents of 19 year olds that can be followed to age 29} \\
\hline Parent Homeowner & 0.55 & 0.50 & 0 & 0 & 1 & 1 & 1 & 682,324 & 0.64 \\
\hline Parent Bankrupt & 0.08 & 0.27 & 0 & 0 & 0 & 0 & 1 & 682,324 & 0.08 \\
\hline Parent Serious Default & 0.18 & 0.39 & 0 & 0 & 0 & 0 & 1 & 682,324 & \\
\hline Parent Delinquency & 0.08 & 0.27 & 0 & 0 & 0 & 0 & 1 & 682,324 & \\
\hline Parent Credit Constrained & 0.33 & 0.32 & 0 & 0.04 & 0.20 & 0.58 & 1 & 547,274 & \\
\hline Parent Equifax Risk Score & 685.1 & 104.1 & 293 & 616 & 710 & 771 & 842 & 657,547 & \\
\hline Parent Age & 48.4 & 8.7 & 34 & 43 & 47 & 52 & 102 & 682,324 & 45.2 \\
\hline Parent Single & 0.22 & 0.41 & 0 & 0 & 0 & 0 & 1 & 682,324 & 0.30 \\
\hline Total Number in Household & 2.8 & 0.4 & 2 & 3 & 3 & 3 & 5 & 682,324 & 3.0 \\
\hline
\end{tabular}

Notes: 1) Authors' calculations using the New York Federal Reserve Bank Consumer Credit Panel/Equifax dataset and the Survey of Consumer Finance (SCF). 2) The table contains statistics of parents of 19 year-olds at time t0 (1999, 2000, 2001, 2002, 2003). If an individual has two parents, an observation for each parent is included. 3) Mean (SCF) is the average for adults aged 34+ with one child aged 18+.4) Mean (SCF) for Total Number in Household is the number of individuals in the household aged $18+$. 
Table 2: Child Summary Statistics

\begin{tabular}{|lcccccccc|}
\hline & Mean & Std. & Min & 25th \% & Median & 75 th \% & Max & Obs. \\
\hline Panel A: Between t0 and t0+5 (Ages 19-24) & & & & & & & & \\
Child Household Formation & 0.50 & 0.50 & 0 & 0 & 0 & 1 & 1 & 523,980 \\
Child Household Formation First Age & 21.6 & 1.5 & 20 & 20 & 21 & 23 & 24 & 259,782 \\
Child Has Credit Card & 0.84 & 0.37 & 0 & 1 & 1 & 1 & 1 & 523,980 \\
Child Has Credit Card First Age & 19.8 & 1.6 & 15 & 19 & 19 & 20 & 24 & 440,434 \\
Child Homeowner & 0.10 & 0.30 & 0 & 0 & 0 & 0 & 1 & 523,980 \\
Child Homeowner First Age & 22.5 & 1.6 & 15 & 22 & 23 & 24 & 24 & 54,123 \\
Child Bankrupt & 0.019 & 0.136 & 0 & 0 & 0 & 0 & 1 & 523,980 \\
Child Foreclosure & 0.077 & 0.266 & 0 & 0 & 0 & 0 & 1 & 523,980 \\
Child Other Serious Default & 0.34 & 0.47 & 0 & 0 & 0 & 1 & 1 & 500,654 \\
Child Delinquency & 0.25 & 0.43 & 0 & 0 & 0 & 0 & 1 & 500,654 \\
Child Equifax Risk Score Average & 632.1 & 78.0 & 312 & 567 & 647.7 & 697.3 & 829 & 511,811 \\
Child Equifax Risk Score End & 635.7 & 98.5 & 288 & 563 & 648 & 721 & 834 & 504,677 \\
Child Credit Constrained & 0.627 & 0.341 & 0 & 0.325 & 0.731 & 0.944 & 1 & 444,942 \\
\hline Panel B: Between t0+6 and t0+10 (Ages $25-29)$ & & & & & & & & \\
Child Household Formation & 0.74 & 0.44 & 0 & 0 & 1 & 1 & 1 & 417,705 \\
Child Household Formation First Age & 22.86 & 2.72 & 20 & 20 & 22 & 25 & 29 & 309,428 \\
Child Has Credit Card & 0.80 & 0.40 & 0 & 1 & 1 & 1 & 1 & 417,705 \\
Child Has Credit Card First Age & 20.18 & 2.36 & 15 & 19 & 19 & 21 & 29 & 377,368 \\
Child Homeowner & 0.28 & 0.45 & 0 & 0 & 0 & 1 & 1 & 417,705 \\
Child Homeowner First Age & 25.24 & 2.61 & 15 & 23 & 25 & 27 & 29 & 123,488 \\
Child Bankrupt & 0.052 & 0.222 & 0 & 0 & 0 & 0 & 1 & 417,705 \\
Child Foreclosure & 0.03 & 0.17 & 0 & 0 & 0 & 0 & 1 & 417,705 \\
Child Other Serious Default & 0.38 & 0.49 & 0 & 0 & 0 & 1 & 1 & 392,930 \\
Child Delinquency & 0.21 & 0.41 & 0 & 0 & 0 & 0 & 1 & 392,930 \\
Child Equifax Risk Score Average & 644.10 & 94.65 & 312 & 565 & 645 & 732.4 & 833 & 411,339 \\
Child Equifax Risk Score End & 654.20 & 102.90 & 310 & 578 & 661 & 746 & 838 & 399,483 \\
Child Credit Constrained & 0.591 & 0.345 & 0 & 0.263 & 0.669 & 0.925 & 1 & 332,024 \\
\hline
\end{tabular}

Notes: 1) Authors' calculations using the New York Federal Reserve Bank Consumer Credit Panel/Equifax dataset. 2) The individuals in Panel A are subsample of the individuals for whom we have an observation at 19 and at 24 years of age. 3) The individuals in Panel B are subsample of the individuals for whom we have an observation at 19 and at 29 years of age. 4) The sample in Panel B is not necessarily a subsample of the sample in Panel A or vice versa. 5) See Table A1 for the summary statistics for individuals at 24 years old who are the subsample of the sample in Panel B. 
Table 3: Representativeness of Sample of Children

\begin{tabular}{|lcccc|}
\hline & \multicolumn{2}{c}{ Age 24 } & \multicolumn{2}{c|}{ Age 29 } \\
& Sample & Full CCP & Sample & Full CCP \\
\hline \hline Child Has Credit Card & 0.70 & 0.56 & 0.66 & 0.55 \\
Child Homeowner & 0.09 & 0.07 & 0.24 & 0.18 \\
Child Bankrupt & 0.018 & 0.015 & 0.051 & 0.038 \\
Child Other Serious Default & 0.23 & 0.24 & 0.22 & 0.24 \\
Child Delinquency & 0.071 & 0.074 & 0.062 & 0.061 \\
Child Equifax Risk Score & 636 & 625 & 654 & 644 \\
Child Has Student Loan & 0.54 & 0.53 & 0.49 & 0.41 \\
Child Credit Constrained & 0.39 & 0.41 & 0.39 & 0.40 \\
\hline
\end{tabular}

Notes: 1) Authors' calculations using the New York Federal Reserve Bank Consumer Credit Panel/Equifax dataset. 2) The Full CCP refers to all individuals of the age indicated in the dataset while "Sample" refers to only those individuals that we use in our analysis. 3) The sample selection is based on the ability to match the children with their parents at age 19 . 
Table 4: Child Credit Outcomes and Parental Default

\begin{tabular}{|c|c|c|c|c|c|c|c|c|c|}
\hline \multirow{2}{*}{$\begin{array}{c}\text { Child } \\
\text { Outcome }\end{array}$} & \multicolumn{2}{|c|}{$\begin{array}{c}\text { Coef. On Parent Serious } \\
\text { Default }\end{array}$} & \multicolumn{2}{|c|}{ Coef. On Parent Age } & \multicolumn{3}{|c|}{ Fixed effects controls } & \multicolumn{2}{|c|}{$\mathrm{R}^{2}$} \\
\hline & $\begin{array}{l}\text { 5-Year } \\
\text { Horizon }\end{array}$ & $\begin{array}{l}\text { 10-Year } \\
\text { Horizon }\end{array}$ & $\begin{array}{l}\text { 5-Year } \\
\text { Horizon }\end{array}$ & $\begin{array}{l}\text { 10-Year } \\
\text { Horizon }\end{array}$ & Cohort & $\begin{array}{l}\text { Zip } \\
\text { Code }\end{array}$ & $\begin{array}{l}\text { State- } \\
\text { Cohort }\end{array}$ & $\begin{array}{l}\text { 5- } \\
\text { Year }\end{array}$ & $\begin{array}{l}10- \\
\text { Year }\end{array}$ \\
\hline \multirow{3}{*}{ Bankruptcy } & $0.014 * * *$ & $0.028 * * *$ & -0.000022 & $-0.00021 * * *$ & Yes & No & No & $0.5 \%$ & $0.6 \%$ \\
\hline & $0.013^{* * *}$ & $0.024 * * *$ & 0.000050 & -0.0000088 & Yes & Yes & No & $6.8 \%$ & $8.8 \%$ \\
\hline & $0.013^{* * *}$ & $0.024 * * *$ & 0.000050 & -0.0000066 & Yes & Yes & Yes & $6.9 \%$ & $8.9 \%$ \\
\hline \multirow{3}{*}{ Delinquency } & $0.14 * * *$ & $0.079 * * *$ & $-0.00098 * * *$ & $-0.00071 * * *$ & Yes & No & No & $2.1 \%$ & $1.1 \%$ \\
\hline & $0.11^{* * *}$ & $0.057 * * *$ & $-0.00072 * * *$ & $-0.00049 * * *$ & Yes & Yes & No & $9.2 \%$ & $9.0 \%$ \\
\hline & $0.11 * * *$ & $0.057 * * *$ & $-0.00072^{* * *}$ & $-0.00049 * * *$ & Yes & Yes & Yes & $9.3 \%$ & $9.1 \%$ \\
\hline \multirow{3}{*}{ Homeowner } & $-0.022 * * *$ & $-0.11^{* * *}$ & $-0.00082^{* * *}$ & $-0.0017^{* * *}$ & Yes & No & No & $0.2 \%$ & $1.4 \%$ \\
\hline & $-0.017 * * *$ & $-0.085^{* * *}$ & $-0.00035 * * *$ & $-0.00097 * * *$ & Yes & Yes & No & $8.1 \%$ & $11.0 \%$ \\
\hline & $-0.017 * * *$ & $-0.085^{* * *}$ & $-0.00035^{* * *}$ & $-0.00097 * * *$ & Yes & Yes & Yes & $8.1 \%$ & $11.0 \%$ \\
\hline \multirow{3}{*}{$\begin{array}{l}\text { Other Serious } \\
\text { Default (Ex. } \\
\text { Foreclos. and } \\
\text { Bankruptcy) }\end{array}$} & $0.30 * * *$ & $0.24 * * *$ & $-0.0011^{* * *}$ & $-0.0013^{* * *}$ & Yes & No & No & $7.3 \%$ & $4.9 \%$ \\
\hline & $0.23^{* * *}$ & $0.18^{* * *}$ & $-0.00087^{* * *}$ & $-0.00098 * * *$ & Yes & Yes & No & $18.0 \%$ & $16.0 \%$ \\
\hline & $0.23 * * *$ & $0.18^{* * *}$ & $-0.00087 * * *$ & $-0.00098 * * *$ & Yes & Yes & Yes & $18.0 \%$ & $17.0 \%$ \\
\hline \multirow{3}{*}{$\begin{array}{l}\text { Average } \\
\text { Equifax Risk } \\
\text { Score }\end{array}$} & $-64.5 * * *$ & $-62.7 * * *$ & $0.31^{* * *}$ & $0.34 * * *$ & Yes & No & No & $13.0 \%$ & $8.4 \%$ \\
\hline & $-50.2 * * *$ & $-46.9 * * *$ & $0.23 * * *$ & $0.25 * * *$ & Yes & Yes & No & $27.0 \%$ & $23.0 \%$ \\
\hline & $-50.2 * * *$ & $-46.9 * * *$ & $0.23^{* * *}$ & $0.25 * * *$ & Yes & Yes & Yes & $27.0 \%$ & $23.0 \%$ \\
\hline \multirow{3}{*}{$\begin{array}{l}\text { Date T } \\
\text { Equifax Risk } \\
\text { Score }\end{array}$} & $-67.3^{* * *}$ & $-62.3^{* * *}$ & $0.42 * * *$ & $0.33^{* * *}$ & Yes & No & No & $8.7 \%$ & $6.9 \%$ \\
\hline & $-51.4^{* * *}$ & $-46.2^{* * *}$ & $0.31^{* * *}$ & $0.24^{* * *}$ & Yes & Yes & No & $21.0 \%$ & $21.0 \%$ \\
\hline & $-51.4^{* * *}$ & $-46.2 * * *$ & $0.31^{* * *}$ & $0.24^{* * *}$ & Yes & Yes & Yes & $21.0 \%$ & $21.0 \%$ \\
\hline \multirow{3}{*}{$\begin{array}{l}\text { Has Credit } \\
\text { Card }\end{array}$} & $-0.094 * * *$ & $-0.14 * * *$ & $0.00039 * * *$ & $0.00042 * *$ & Yes & No & No & $1.2 \%$ & $2.3 \%$ \\
\hline & $-0.065^{* * *}$ & $-0.099 * * *$ & $0.00014^{* *}$ & 0.00014 & Yes & Yes & No & $11.0 \%$ & $13.0 \%$ \\
\hline & $-0.065^{* * *}$ & $-0.099 * * *$ & $0.00014^{* *}$ & 0.00014 & Yes & Yes & Yes & $11.0 \%$ & $13.0 \%$ \\
\hline
\end{tabular}

Note: 1) Results using data from the New York Federal Reserve Bank Consumer Credit Panel/Equifax dataset. 2) Each row of table presents results from two regressions of child outcome variable on parental variables indicated and fixed effects. 
Table 5: Child Credit Outcomes and Parental Credit Constraints

\begin{tabular}{|c|c|c|c|c|c|c|c|c|c|}
\hline \multirow{2}{*}{$\begin{array}{c}\text { Child } \\
\text { Outcome }\end{array}$} & \multicolumn{2}{|c|}{$\begin{array}{l}\text { Coef. On Parent Credit } \\
\text { Constrained }\end{array}$} & \multicolumn{2}{|c|}{ Coef. On Parent Age } & \multicolumn{3}{|c|}{ Fixed effects controls } & \multicolumn{2}{|c|}{$\mathrm{R}^{2}$} \\
\hline & $\begin{array}{l}\text { 5-Year } \\
\text { Horizon }\end{array}$ & $\begin{array}{l}\text { 10-Year } \\
\text { Horizon }\end{array}$ & $\begin{array}{l}\text { 5-Year } \\
\text { Horizon }\end{array}$ & $\begin{array}{l}\text { 10-Year } \\
\text { Horizon }\end{array}$ & Cohort & $\begin{array}{l}\text { Zip } \\
\text { Code }\end{array}$ & $\begin{array}{l}\text { State- } \\
\text { Cohort }\end{array}$ & $\begin{array}{c}5- \\
\text { Year }\end{array}$ & $\begin{array}{l}10- \\
\text { Year }\end{array}$ \\
\hline \multirow{3}{*}{ Bankruptcy } & $0.016 * * *$ & $0.034 * * *$ & -0.0000027 & $-0.00022 * *$ & Yes & No & No & $0 \%$ & $1 \%$ \\
\hline & $0.014 * * *$ & $0.028 * * *$ & $0.000063^{*}$ & -0.000017 & Yes & Yes & No & $8 \%$ & $10 \%$ \\
\hline & $0.014^{* * *}$ & $0.028 * * *$ & $0.000062 *$ & -0.000014 & Yes & Yes & Yes & $8 \%$ & $10 \%$ \\
\hline \multirow{3}{*}{ Delinquency } & $0.20 * * *$ & $0.13^{* * *}$ & $-0.00056^{* * *}$ & $-0.00042 * *$ & Yes & No & No & $3 \%$ & $2 \%$ \\
\hline & $0.17 * * *$ & $0.11^{* * *}$ & $-0.00038 * *$ & $-0.00024^{*}$ & Yes & Yes & No & $10 \%$ & $10 \%$ \\
\hline & $0.17 * * *$ & $0.11^{* * *}$ & $-0.00038 * *$ & $-0.00024 *$ & Yes & Yes & Yes & $11 \%$ & $10 \%$ \\
\hline \multirow{3}{*}{ Homeowner } & $-0.025 * * *$ & $-0.14 * * *$ & $-0.0014 * * *$ & $-0.0030 * * *$ & Yes & No & No & $0 \%$ & $2 \%$ \\
\hline & $-0.025^{* * *}$ & $-0.12 * * *$ & $-0.00076^{* * *}$ & $-0.0020 * * *$ & Yes & Yes & No & $9 \%$ & $11 \%$ \\
\hline & $-0.025 * * *$ & $-0.12 * * *$ & $-0.00076^{* * *}$ & $-0.0020 * * *$ & Yes & Yes & Yes & $9 \%$ & $12 \%$ \\
\hline \multirow{3}{*}{$\begin{array}{l}\text { Other Serious } \\
\text { Default (Ex. } \\
\text { Foreclos. and } \\
\text { Bankruptcy) }\end{array}$} & $0.33^{* * *}$ & $0.30 * * *$ & -0.0000027 & -0.00033 & Yes & No & No & $6 \%$ & $5 \%$ \\
\hline & $0.26^{* * *}$ & $0.24 * * *$ & 0.000015 & -0.00020 & Yes & Yes & No & $17 \%$ & $17 \%$ \\
\hline & $0.26^{* * *}$ & $0.24^{* * *}$ & 0.000015 & -0.00019 & Yes & Yes & Yes & $17 \%$ & $17 \%$ \\
\hline \multirow{3}{*}{$\begin{array}{l}\text { Average } \\
\text { Equifax Risk } \\
\text { Score }\end{array}$} & $-79.6 * * *$ & $-85.2 * * *$ & 0.055 & 0.052 & Yes & No & No & $13 \%$ & $10 \%$ \\
\hline & $-65.2 * * *$ & $-69.0 * * *$ & 0.011 & 0.0085 & Yes & Yes & No & $27 \%$ & $23 \%$ \\
\hline & $-65.2 * * *$ & $-69.0 * * *$ & 0.012 & 0.0075 & Yes & Yes & Yes & $27 \%$ & $23 \%$ \\
\hline \multirow{3}{*}{$\begin{array}{l}\text { Date T } \\
\text { Equifax Risk } \\
\text { Score }\end{array}$} & $-87.7^{* * * *}$ & $-83.8 * * *$ & $0.14 * *$ & 0.036 & Yes & No & No & $10 \%$ & $8 \%$ \\
\hline & $-71.4^{* * *}$ & $-67.4 * * *$ & $0.079 * *$ & -0.0092 & Yes & Yes & No & $21 \%$ & $21 \%$ \\
\hline & $-71.4^{* * *}$ & $-67.4^{* * *}$ & $0.078 * *$ & -0.0094 & Yes & Yes & Yes & $21 \%$ & $21 \%$ \\
\hline \multirow{3}{*}{$\begin{array}{l}\text { Has Credit } \\
\text { Card }\end{array}$} & $-0.095 * * *$ & $-0.14^{* * *}$ & $-0.00039 * *$ & $-0.00040^{*}$ & Yes & No & No & $1 \%$ & $2 \%$ \\
\hline & $-0.070 * * *$ & $-0.11^{* * *}$ & $-0.00054^{* * *}$ & $-0.00054 * * *$ & Yes & Yes & No & $10 \%$ & $12 \%$ \\
\hline & $-0.069 * * *$ & $-0.11^{* * *}$ & $-0.00053^{* * *}$ & $-0.00054 * * *$ & Yes & Yes & Yes & $11 \%$ & $13 \%$ \\
\hline
\end{tabular}

Notes: 1) Results using data from the New York Federal Reserve Bank Consumer Credit Panel/Equifax dataset. 2) Each row in the table presents results from two regressions for child outcome variable on parental variables indicated and fixed effects. 
Table 6: Child Credit Outcomes and Parental Equifax Risk Score

\begin{tabular}{|c|c|c|c|c|c|c|c|c|c|}
\hline \multirow{2}{*}{$\begin{array}{c}\text { Child } \\
\text { Outcome }\end{array}$} & \multicolumn{2}{|c|}{$\begin{array}{c}\text { Coef. On Parent Equifax Risk } \\
\text { Score }\end{array}$} & \multicolumn{2}{|c|}{ Coef. On Parent Age } & \multicolumn{3}{|c|}{ Fixed effects controls } & \multicolumn{2}{|c|}{$\mathrm{R}^{2}$} \\
\hline & $\begin{array}{l}\text { 5-Year } \\
\text { Horizon }\end{array}$ & $\begin{array}{l}\text { 10-Year } \\
\text { Horizon }\end{array}$ & $\begin{array}{l}\text { 5-Year } \\
\text { Horizon }\end{array}$ & $\begin{array}{l}\text { 10-Year } \\
\text { Horizon }\end{array}$ & Cohort & $\begin{array}{l}\text { Zip } \\
\text { Code }\end{array}$ & $\begin{array}{l}\text { State- } \\
\text { Cohort }\end{array}$ & $\begin{array}{l}5- \\
\text { Year }\end{array}$ & $\begin{array}{l}10- \\
\text { Year }\end{array}$ \\
\hline \multirow{3}{*}{ Bankruptcy } & $-0.000071 * * *$ & $-0.00014 * * *$ & 0.000052 & -0.000085 & Yes & No & No & $1 \%$ & $1 \%$ \\
\hline & $-0.000064 * * *$ & $-0.00012^{* * *}$ & $0.00012^{* * *}$ & 0.000092 & Yes & Yes & No & $7 \%$ & $9 \%$ \\
\hline & $-0.000064 * * *$ & $-0.00012^{* * *}$ & $0.00012^{* * *}$ & 0.000095 & Yes & Yes & Yes & $7 \%$ & $9 \%$ \\
\hline \multirow{3}{*}{ Delinquency } & $-0.00097 * * *$ & $-0.00057 * * *$ & $0.00047 * * *$ & 0.00015 & Yes & No & No & $5 \%$ & $2 \%$ \\
\hline & $-0.00086 * * *$ & $-0.00046 * * *$ & $0.00052^{* * *}$ & 0.00018 & Yes & Yes & No & $12 \%$ & $10 \%$ \\
\hline & $-0.00086^{* * *}$ & $-0.00046 * * *$ & $0.00052^{* * *}$ & 0.00018 & Yes & Yes & Yes & $12 \%$ & $10 \%$ \\
\hline \multirow{3}{*}{ Homeowner } & $0.00012^{* * *}$ & $0.00069 * * *$ & $-0.0011 * * *$ & $-0.0030 * * *$ & Yes & No & No & $0 \%$ & $3 \%$ \\
\hline & $0.00012^{* * *}$ & $0.00062 * * *$ & $-0.00063 * * *$ & $-0.0021^{* * *}$ & Yes & Yes & No & $8 \%$ & $12 \%$ \\
\hline & $0.00012 * * *$ & $0.00062 * * *$ & $-0.00063 * * *$ & $-0.0021^{* * *}$ & Yes & Yes & Yes & $8 \%$ & $12 \%$ \\
\hline \multirow{3}{*}{$\begin{array}{l}\text { Other Serious } \\
\text { Default (Ex. } \\
\text { Foreclos. and } \\
\text { Bankruptcy) }\end{array}$} & $-0.0019 * * *$ & $-0.0016^{* * *}$ & $0.0017 * * *$ & $0.0011^{* * *}$ & Yes & No & No & $16 \%$ & $11 \%$ \\
\hline & $-0.0016 * * *$ & $-0.0013^{* * *}$ & $0.0014^{* * *}$ & $0.00088^{* * *}$ & Yes & Yes & No & $23 \%$ & $20 \%$ \\
\hline & $-0.0016 * * *$ & $-0.0013^{* * *}$ & $0.0014^{* * *}$ & $0.00088 * * *$ & Yes & Yes & Yes & $23 \%$ & $20 \%$ \\
\hline \multirow{3}{*}{$\begin{array}{l}\text { Average } \\
\text { Equifax Risk } \\
\text { Score }\end{array}$} & $0.42^{* * *}$ & $0.42 * * *$ & $-0.32 * * *$ & $-0.31 * * *$ & Yes & No & No & $30 \%$ & $21 \%$ \\
\hline & $0.36 * * *$ & $0.35^{* * *}$ & $-0.29 * * *$ & $-0.27 * * *$ & Yes & Yes & No & $38 \%$ & $30 \%$ \\
\hline & $0.36^{* * *}$ & $0.35^{* * *}$ & $-0.29 * * *$ & $-0.27 * * *$ & Yes & Yes & Yes & $38 \%$ & $30 \%$ \\
\hline \multirow{3}{*}{$\begin{array}{l}\text { Date T } \\
\text { Equifax Risk } \\
\text { Score }\end{array}$} & $0.45^{* * *}$ & $0.42 * * *$ & $-0.26 * * *$ & $-0.32 * * *$ & Yes & No & No & $21 \%$ & $17 \%$ \\
\hline & $0.38 * * *$ & $0.34 * * *$ & $-0.24 * * *$ & $-0.27 * * *$ & Yes & Yes & No & $29 \%$ & $26 \%$ \\
\hline & $0.38^{* * *}$ & $0.34^{* * *}$ & $-0.24 * * *$ & $-0.27 * * *$ & Yes & Yes & Yes & $29 \%$ & $26 \%$ \\
\hline \multirow{3}{*}{$\begin{array}{l}\text { Has Credit } \\
\text { Card }\end{array}$} & $0.00066^{* * *}$ & $0.00093 * * *$ & $-0.00072 * * *$ & $-0.0011 * * *$ & Yes & No & No & $3 \%$ & $6 \%$ \\
\hline & $0.00050 * * *$ & $0.00073 * * *$ & $-0.00070 * * *$ & $-0.00099 * * *$ & Yes & Yes & No & $12 \%$ & $15 \%$ \\
\hline & $0.00050 * * *$ & $0.00073^{* * *}$ & $-0.00069 * * *$ & $-0.00099 * * *$ & Yes & Yes & Yes & $12 \%$ & $15 \%$ \\
\hline
\end{tabular}

Notes: 1) Results using data from the New York Federal Reserve Bank Consumer Credit Panel/Equifax dataset. 2) Each row of table presents results from two regressions for the indicated child outcome variable on parental variables indicated and fixed effects. 
Table 7: Economic Effect of One Standard Deviation Increase in Parental Credit Attributes on Child Credit Outcomes

\begin{tabular}{|c|c|c|c|c|c|c|c|c|}
\hline \multirow{3}{*}{ Child Outcome } & \multicolumn{4}{|c|}{ Parent Credit Constrained } & \multicolumn{4}{|c|}{ Parent Equifax Risk Score } \\
\hline & \multicolumn{2}{|c|}{ 5-Year Horizon } & \multicolumn{2}{|c|}{ 10-Year Horizon } & \multicolumn{2}{|c|}{ 5-Year Horizon } & \multicolumn{2}{|c|}{ 10-Year Horizon } \\
\hline & Level & $\begin{array}{l}\text { Percent } \\
\text { of mean }\end{array}$ & Level & $\begin{array}{l}\text { Percent } \\
\text { of mean }\end{array}$ & Level & $\begin{array}{l}\text { Percent } \\
\text { of mean }\end{array}$ & Level & $\begin{array}{l}\text { Percent } \\
\text { of mean }\end{array}$ \\
\hline Bankruptcy & 0.004 & $24 \%$ & 0.009 & $17 \%$ & -0.007 & $-35 \%$ & -0.012 & $-24 \%$ \\
\hline Delinquency & 0.055 & $22 \%$ & 0.035 & $17 \%$ & -0.090 & $-36 \%$ & -0.048 & $-23 \%$ \\
\hline Homeowner & -0.008 & $-8 \%$ & -0.039 & $-14 \%$ & 0.013 & $12 \%$ & 0.065 & $23 \%$ \\
\hline $\begin{array}{l}\text { Other Serious Default (Ex. } \\
\text { Foreclosure and Bankruptcy) }\end{array}$ & 0.083 & $25 \%$ & 0.077 & $20 \%$ & -0.167 & $-49 \%$ & -0.135 & $-36 \%$ \\
\hline Average Equifax Risk Score & -20.9 & $-3 \%$ & -22.2 & $-3 \%$ & 37.5 & $6 \%$ & 36.4 & $6 \%$ \\
\hline End-of-period Equifax Risk Score & -22.9 & $-4 \%$ & -21.7 & $-3 \%$ & 39.6 & $6 \%$ & 35.4 & $6 \%$ \\
\hline Has Credit Card & -0.022 & $-3 \%$ & -0.035 & $-4 \%$ & 0.052 & $6 \%$ & 0.076 & $9 \%$ \\
\hline
\end{tabular}

Notes: 1) Results using data from the New York Federal Reserve Bank Consumer Credit Panel/Equifax dataset. 2) The table presents results from OLS estimation with zip code fixed effects from Tables 3-5. 
Table 8: Parental Credit Characteristics and Presence of Student Loans for Child Within 5 Years

Panel A: Parental Credit Constrained

\begin{tabular}{|c|c|c|cc|c|}
\hline Child Outcome & $\begin{array}{c}\text { Parental Income } \\
\text { Quintile }\end{array}$ & $\begin{array}{c}\text { Coef. On Parent } \\
\text { Credit } \\
\text { Constrained }\end{array}$ & Fixed effects controls & $\mathrm{R}^{2}$ \\
\hline \hline \multirow{3}{*}{ Student Loan } & Cowest & $0.037^{* * *}$ & Yes & Yes & $7.1 \%$ \\
& 2 & $0.076^{* * *}$ & Yes & Yes & $8.6 \%$ \\
& 3 & $0.087^{* * *}$ & Yes & Yes & $8.9 \%$ \\
& 4 & $0.13^{* * *}$ & Yes & Yes & $11.0 \%$ \\
& Highest & $0.21^{* * *}$ & Yes & Yes & $11.0 \%$ \\
\hline
\end{tabular}

Panel B: Parental Default

\begin{tabular}{|c|c|c|cc|c|}
\hline Child Outcome & $\begin{array}{c}\text { Parental Income } \\
\text { Quintile }\end{array}$ & $\begin{array}{c}\text { Coef. On Parent } \\
\text { Default }\end{array}$ & Fixed effects controls & $\mathrm{R}^{2}$ \\
\hline \hline \multirow{3}{*}{ Student Loan } & Lowest & 0.00072 & Yes & Yes & $6.9 \%$ \\
& 2 & 0.0068 & Yes & Yes & $8.2 \%$ \\
& 3 & $0.018^{*}$ & Yes & Yes & $8.5 \%$ \\
& 4 & $0.028^{* * *}$ & Yes & Yes & $10.0 \%$ \\
& Highest & $0.091^{* * *}$ & Yes & Yes & $10.0 \%$ \\
\hline
\end{tabular}

Panel C: Parental Equifax Risk Score

\begin{tabular}{|c|c|c|cc|c|}
\hline Child Outcome & $\begin{array}{c}\text { Parental Income } \\
\text { Quintile }\end{array}$ & $\begin{array}{c}\text { Coef. On Parent } \\
\text { Equifax Risk } \\
\text { Score }\end{array}$ & Fixed effects controls & $\mathrm{R}^{2}$ \\
\hline \hline \multirow{3}{*}{ Student Loan } & Lowest & 0.00002 & Yes & Yes & $6.9 \%$ \\
& 2 & $-0.00014^{* * *}$ & Yes & Yes & $8.3 \%$ \\
& 3 & $-0.00029^{* * *}$ & Yes & Yes & $8.7 \%$ \\
& 4 & $-0.00050^{* * *}$ & Yes & Yes & $11.0 \%$ \\
& Highest & $-0.0013^{* * *}$ & Yes & Yes & $12.0 \%$ \\
\hline \hline
\end{tabular}

Notes: 1) Sample of parents in 2005-2008 rather than benchmark sample. 2) Parental income quintiles are formed based on predicted parental income from CRISM sample. 3) Note: Results using data from the New York Federal Reserve Bank Consumer Credit Panel/Equifax and Equifax Credit Risk Insight Servicing McDash (CRISM). 
Table 9: Geographic Variables and Strength of Intergenerational Linkages between Child Credit Outcomes and Parental Credit Constraints

\begin{tabular}{|c|c|c|c|c|c|c|c|c|}
\hline \multirow{2}{*}{$\begin{array}{l}\text { Child } \\
\text { Outcome }\end{array}$} & \multirow{2}{*}{$\begin{array}{l}\text { Covariate } \\
\text { Specification }\end{array}$} & \multicolumn{2}{|c|}{$\begin{array}{l}\text { Coef. On Parent } \\
\text { Constrained }\end{array}$} & \multicolumn{2}{|c|}{$\begin{array}{l}\text { Coef. On (Parent Constrained) * } \\
\text { Geographical Variable }\end{array}$} & \multicolumn{3}{|c|}{ Other Controls } \\
\hline & & $\begin{array}{l}\text { 5-Year } \\
\text { Horizon }\end{array}$ & $\begin{array}{l}\text { 10-Year } \\
\text { Horizon }\end{array}$ & 5-Year Horizon & 10-Year Horizon & Cohort & $\begin{array}{l}\text { Zip } \\
\text { Code }\end{array}$ & $\begin{array}{l}\text { Parent } \\
\text { Age }\end{array}$ \\
\hline \multirow{8}{*}{ Delinquency } & None (Benchmk) & $0.20 * * *$ & $0.13 * * *$ & $\mathrm{x}$ & $\mathrm{x}$ & Yes & Yes & Yes \\
\hline & HH Inc. per Capita & $0.15 * * *$ & $0.066 * * *$ & 0.00000048 & $0.0000010^{* * *}$ & Yes & Yes & Yes \\
\hline & \% Middle Class & $0.16 * * *$ & $0.100 * * *$ & 0.011 & 0.012 & Yes & Yes & Yes \\
\hline & Gini & $0.20 * * *$ & $0.13^{* * *}$ & $-0.073 * * *$ & $-0.064 * * *$ & Yes & Yes & Yes \\
\hline & Inc. Segregation & $0.18^{* * *}$ & $0.11^{* * *}$ & $-0.15^{*}$ & -0.088 & Yes & Yes & Yes \\
\hline & $\%$ Black & $0.17 * * *$ & $0.11^{* * *}$ & -0.00099 & -0.031 & Yes & Yes & Yes \\
\hline & Rel. Immobility & $0.11^{* * *}$ & $0.071^{* * *}$ & $0.17 * * *$ & $0.10^{* *}$ & Yes & Yes & Yes \\
\hline & Abs. Mobility & $0.19 * * *$ & $0.095 * *$ & -0.00044 & 0.00026 & Yes & Yes & Yes \\
\hline \multirow{8}{*}{ Homeowner } & None (Benchmk) & $-0.025 * * *$ & $-0.14^{* * *}$ & $\mathrm{x}$ & $\mathrm{x}$ & Yes & Yes & Yes \\
\hline & HH Inc. per Capita & $-0.066 * * *$ & $-0.18^{* * *}$ & $0.0000010 * * *$ & $0.0000013^{* * *}$ & Yes & Yes & Yes \\
\hline & \% Middle Class & $0.028 *$ & -0.03 & $-0.11 * * *$ & $-0.19 * * *$ & Yes & Yes & Yes \\
\hline & Gini & $-0.041 * * *$ & $-0.17^{* * *}$ & 0.037 & $0.11^{* * *}$ & Yes & Yes & Yes \\
\hline & Inc. Segregation & $-0.042 * * *$ & $-0.15^{* * *}$ & $0.23 * * *$ & $0.43^{* * *}$ & Yes & Yes & Yes \\
\hline & \% Black & $-0.021 * * *$ & $-0.12 * * *$ & $-0.034 *$ & -0.016 & Yes & Yes & Yes \\
\hline & Rel. Immobility & 0.016 & -0.029 & $-0.12 * *$ & $-0.26 * * *$ & Yes & Yes & Yes \\
\hline & Abs. Mobility & $-0.14 * * *$ & $-0.30 * * *$ & $0.0028 * * *$ & $0.0045 * * *$ & Yes & Yes & Yes \\
\hline \multirow{8}{*}{$\begin{array}{l}\text { Date T } \\
\text { Equifax Risk } \\
\text { Score }\end{array}$} & None (Benchmk) & $-87.7 * * * *$ & $-83.8 * * *$ & $\mathrm{X}$ & $\mathrm{x}$ & Yes & Yes & Yes \\
\hline & HH Inc. per Capita & $-65.3 * * *$ & $-60.2 * * *$ & $-0.00015^{* * *}$ & $-0.00018 *$ & Yes & Yes & Yes \\
\hline & \% Middle Class & $-75.9 * * *$ & $-69.4^{* * *}$ & 9.17 & 4.04 & Yes & Yes & Yes \\
\hline & Gini & $-75.1 * * *$ & $-72.0 * * *$ & 8.37 & 10.3 & Yes & Yes & Yes \\
\hline & Inc. Segregation & $-73.0 * * *$ & $-69.4^{* * *}$ & 20.3 & 26.2 & Yes & Yes & Yes \\
\hline & \% Black & $-69.9 * * *$ & $-65.8 * * *$ & $-13.0 * *$ & $-13.9 *$ & Yes & Yes & Yes \\
\hline & Rel. Immobility & $-44.9 * * *$ & $-38.3^{* * *}$ & $-78.0 * * *$ & $-85.5 * * *$ & Yes & Yes & Yes \\
\hline & Abs. Mobility & $-85.3 * * *$ & $-87.8 * * *$ & 0.34 & 0.51 & Yes & Yes & Yes \\
\hline \multirow{8}{*}{$\begin{array}{l}\text { Has Credit } \\
\text { Card }\end{array}$} & None (Benchmk) & $-0.095 * * *$ & $-0.14^{* * *}$ & $\mathrm{x}$ & $\mathrm{x}$ & Yes & Yes & Yes \\
\hline & HH Inc. per Capita & $-0.11 * * *$ & $-0.18 * * *$ & $0.0000011^{* * *}$ & $0.0000018^{* * *}$ & Yes & Yes & Yes \\
\hline & \% Middle Class & $-0.040^{*}$ & $-0.062 * * *$ & -0.06 & $-0.092^{* *}$ & Yes & Yes & Yes \\
\hline & Gini & $-0.076^{* * *}$ & $-0.091 * * *$ & 0.013 & -0.039 & Yes & Yes & Yes \\
\hline & Inc. Segregation & $-0.084 * * *$ & $-0.12^{* * *}$ & $0.18 * * *$ & $0.17 * * *$ & Yes & Yes & Yes \\
\hline & \% Black & $-0.071^{* * *}$ & $-0.10 * * *$ & 0.012 & $-0.055^{* *}$ & Yes & Yes & Yes \\
\hline & Rel. Immobility & $-0.041^{* *}$ & $-0.065^{* * *}$ & $-0.080^{*}$ & $-0.12^{* * *}$ & Yes & Yes & Yes \\
\hline & Abs. Mobility & $-0.18 * * *$ & $-0.23 * * *$ & $0.0026 * * *$ & $0.0030 * * *$ & Yes & Yes & Yes \\
\hline
\end{tabular}

Note: Results using data from the New York Federal Reserve Bank Consumer Credit Panel/Equifax dataset and other data sources as described in the text. 
Table 10: Geographic Variables and Strength of Intergenerational Linkages between Child Credit Outcomes and Parental Equifax Risk Score

\begin{tabular}{|c|c|c|c|c|c|c|c|c|}
\hline \multirow{2}{*}{ Child Outcome } & \multirow{2}{*}{$\begin{array}{c}\text { Covariate } \\
\text { Specification }\end{array}$} & \multicolumn{2}{|c|}{$\begin{array}{c}\text { Coef. On Parent Equifax Risk } \\
\text { Score }\end{array}$} & \multicolumn{2}{|c|}{$\begin{array}{c}\text { Coef. On (Parent Equifax Risk Score) * } \\
\text { Geographical Variable }\end{array}$} & \multicolumn{3}{|c|}{ Other Controls } \\
\hline & & $\begin{array}{l}\text { 5-Year } \\
\text { Horizon }\end{array}$ & $\begin{array}{l}\text { 10-Year } \\
\text { Horizon }\end{array}$ & 5-Year Horizon & 10-Year Horizon & Cohort & $\begin{array}{l}\text { Zip } \\
\text { Code }\end{array}$ & $\begin{array}{l}\text { Parent } \\
\text { Age }\end{array}$ \\
\hline \multirow{8}{*}{ Delinquency } & None (Benchmk) & $-0.00086 * * *$ & $-0.00046 * * *$ & $\mathrm{x}$ & $\mathrm{x}$ & Yes & Yes & Yes \\
\hline & HH Inc. per Capita & $-0.00062 * * *$ & $-0.00021 * * *$ & $-6.2 \mathrm{e}-09 * * *$ & $-6.5 \mathrm{e}-09 * * *$ & Yes & Yes & Yes \\
\hline & \% Middle Class & $-0.00087 * * *$ & $-0.00051 * * *$ & 0.000015 & 0.000085 & Yes & Yes & Yes \\
\hline & Gini & $-0.0011^{* * *}$ & $-0.00061 * * *$ & $0.00049 * * *$ & $0.00033 * * *$ & Yes & Yes & Yes \\
\hline & Inc. Segregation & $-0.00091^{* * *}$ & $-0.00048 * * *$ & $0.00055^{* * *}$ & 0.00026 & Yes & Yes & Yes \\
\hline & \% Black & $-0.00090 * * *$ & $-0.00050 * * *$ & $0.00030 * * *$ & $0.00026^{* * *}$ & Yes & Yes & Yes \\
\hline & Rel. Immobility & $-0.00075^{* * *}$ & $-0.00044 * * *$ & $-0.00032 *$ & -0.00007 & Yes & Yes & Yes \\
\hline & Abs. Mobility & $-0.00055 * * *$ & -0.000026 & $-0.0000075^{*}$ & $-0.000011^{* * *}$ & Yes & Yes & Yes \\
\hline \multirow{8}{*}{ Homeownership } & None (Benchmk) & $0.00012^{* * *}$ & $0.00062 * * *$ & $\mathrm{x}$ & $\mathrm{x}$ & Yes & Yes & Yes \\
\hline & HH Inc. per Capita & $0.00036 * * *$ & $0.00093 * * *$ & $-6.0 \mathrm{e}-09 * * *$ & $-7.8 \mathrm{e}-09 * * *$ & Yes & Yes & Yes \\
\hline & \% Middle Class & $-0.00017 * *$ & 0.000065 & $0.00058 * * *$ & $0.0011^{* * *}$ & Yes & Yes & Yes \\
\hline & Gini & $0.00021^{* * *}$ & $0.00094 * * *$ & $-0.00019 *$ & $-0.00071^{* * *}$ & Yes & Yes & Yes \\
\hline & Inc. Segregation & $0.00021^{* * *}$ & $0.00081^{* * *}$ & $-0.0012 * * *$ & $-0.0025^{* * *}$ & Yes & Yes & Yes \\
\hline & \% Black & $0.00011^{* * *}$ & $0.00063 * * *$ & 0.0001 & -0.0001 & Yes & Yes & Yes \\
\hline & Rel. Immobility & $-0.00011^{*}$ & 0.00011 & $0.00066 * * *$ & $0.0014 * * *$ & Yes & Yes & Yes \\
\hline & Abs. Mobility & $0.00075^{* * *}$ & $0.0015^{* * *}$ & $-0.000016^{* * *}$ & $-0.000022^{* *}$ & Yes & Yes & Yes \\
\hline \multirow{8}{*}{$\begin{array}{l}\text { Date T Equifax Risk } \\
\text { Score }\end{array}$} & None (Benchmk) & $0.38 * * *$ & $0.34 * * *$ & $\mathrm{x}$ & $\mathrm{x}$ & Yes & Yes & Yes \\
\hline & HH Inc. per Capita & $0.32 * * *$ & $0.30 * * *$ & $0.0000014^{* * *}$ & $0.0000012^{* * *}$ & Yes & Yes & Yes \\
\hline & \% Middle Class & $0.39 * * *$ & $0.35 * * *$ & -0.022 & -0.008 & Yes & Yes & Yes \\
\hline & Gini & $0.42 * * *$ & $0.38 * * *$ & $-0.097 * * *$ & $-0.093 * * *$ & Yes & Yes & Yes \\
\hline & Inc. Segregation & $0.39 * * *$ & $0.36 * * *$ & $-0.16 * * *$ & $-0.17 * * *$ & Yes & Yes & Yes \\
\hline & \% Black & $0.38 * * *$ & $0.34 * * *$ & $-0.047^{*}$ & -0.019 & Yes & Yes & Yes \\
\hline & Rel. Immobility & $0.30 * * *$ & $0.24 * * *$ & $0.23 * * *$ & $0.29 * * *$ & Yes & Yes & Yes \\
\hline & Abs. Mobility & $0.35^{* * *}$ & $0.35^{* * *}$ & 0.00068 & -0.00019 & Yes & Yes & Yes \\
\hline \multirow{8}{*}{ Has Credit Card } & None (Benchmk) & $0.00050 * * *$ & $0.00073^{* * *}$ & $\mathrm{X}$ & $\mathrm{X}$ & Yes & Yes & Yes \\
\hline & HH Inc. per Capita & $0.00094 * * *$ & $0.0012 * * *$ & $-0.000000011^{* * *}$ & $-0.000000011^{* * *}$ & Yes & Yes & Yes \\
\hline & \% Middle Class & 0.000035 & $0.00033^{* * *}$ & $0.00094 * * *$ & $0.00080 * * *$ & Yes & Yes & Yes \\
\hline & Gini & $0.00065 * * *$ & $0.00079 * * *$ & $-0.00032 * *$ & -0.00014 & Yes & Yes & Yes \\
\hline & Inc. Segregation & $0.00065 * * *$ & $0.00086 * * *$ & $-0.0019 * * *$ & $-0.0018 * * *$ & Yes & Yes & Yes \\
\hline & \% Black & $0.00052 * * *$ & $0.00073 * * *$ & -0.00015 & $-3.6 e-08$ & Yes & Yes & Yes \\
\hline & Rel. Immobility & $0.00026 * *$ & $0.00047 * * *$ & $0.00064^{* *}$ & $0.00068 * * *$ & Yes & Yes & Yes \\
\hline & Abs. Mobility & $0.0013^{* * *}$ & $0.0014^{* * *}$ & $-0.000020 * * *$ & $-0.000018 * * *$ & Yes & Yes & Yes \\
\hline
\end{tabular}

Note: Results using data from the New York Federal Reserve Bank Consumer Credit Panel/Equifax dataset and other data sources as described in the text. 
Table 11: Educational Policies and Strength of Intergenerational Linkages between Child Credit Outcomes and Parental Credit Constraints

\begin{tabular}{|c|c|c|c|c|c|c|c|c|c|c|}
\hline \multirow{2}{*}{ Child Outcome } & \multirow{2}{*}{ Covariate Specification } & \multicolumn{2}{|c|}{ Coef. On Parent Constrained } & \multicolumn{2}{|c|}{$\begin{array}{l}\text { Coef. On Educational } \\
\text { Policy }\end{array}$} & \multicolumn{2}{|c|}{$\begin{array}{l}\text { Coef. On (Parent Constrained) * } \\
\text { Educational Policy }\end{array}$} & \multicolumn{3}{|c|}{ Other Controls } \\
\hline & & $\begin{array}{l}\text { 5-Year } \\
\text { Horizon }\end{array}$ & $\begin{array}{l}\text { 10-Year } \\
\text { Horizon }\end{array}$ & $\begin{array}{l}\text { 5-Year } \\
\text { Horizon }\end{array}$ & $\begin{array}{l}\text { 10-Year } \\
\text { Horizon }\end{array}$ & 5-Year Horizon & 10-Year Horizon & Cohort & $\begin{array}{l}\text { Zip } \\
\text { Code }\end{array}$ & $\begin{array}{l}\text { Parent } \\
\text { Age }\end{array}$ \\
\hline \multirow{5}{*}{ Delinquency } & None (Benchmark) & $0.17 * * *$ & $0.11^{* * *}$ & $\mathrm{x}$ & $\mathrm{x}$ & $\mathrm{x}$ & $\mathrm{x}$ & Yes & Yes & Yes \\
\hline & Sch. Spending per Pupil & $0.14^{* * *}$ & $0.072 * * *$ & $\mathrm{x}$ & $\mathrm{x}$ & $0.0000035^{* *}$ & $0.0000043^{* * *}$ & Yes & Yes & Yes \\
\hline & Financial Literacy & $0.17 * * *$ & $0.11 * * *$ & -0.0041 & 0.0052 & 0.0053 & -0.00094 & Yes & Yes & Yes \\
\hline & Economic Literacy & $0.17 * * *$ & $0.11^{* * *}$ & $0.017 * * *$ & $0.051 * * *$ & -0.0051 & $-0.016 * * *$ & Yes & Yes & Yes \\
\hline & Math Curr. Improvement & $0.17 * * *$ & $0.10 * * *$ & 0.0031 & $-0.0088 *$ & 0.0074 & $0.011^{*}$ & Yes & Yes & Yes \\
\hline \multirow{5}{*}{ Homeownership } & None (Benchmark) & $-0.025 * * *$ & $-0.12 * * *$ & $\mathrm{x}$ & $\mathrm{x}$ & $\mathrm{x}$ & $\mathrm{x}$ & Yes & Yes & Yes \\
\hline & Sch. Spending per Pupil & $-0.071 * * *$ & $-0.18 * * *$ & $\mathrm{x}$ & $\mathrm{x}$ & $0.0000059 * * *$ & $0.0000075^{* * *}$ & Yes & Yes & Yes \\
\hline & Financial Literacy & $-0.026 * * *$ & $-0.12^{* * *}$ & -0.0018 & $-0.012^{* * *}$ & $0.016^{* * *}$ & $0.029 * * *$ & Yes & Yes & Yes \\
\hline & Economic Literacy & $-0.024 * * *$ & $-0.12 * * *$ & 0.0013 & -0.00016 & -0.0022 & 0.0033 & Yes & Yes & Yes \\
\hline & Math Curr. Improvement & $-0.023 * * *$ & $-0.12^{* * *}$ & -0.0085 & -0.001 & -0.0073 & -0.013 & Yes & Yes & Yes \\
\hline \multirow{5}{*}{$\begin{array}{l}\text { Date T Equifax } \\
\text { Risk Score }\end{array}$} & None (Benchmark) & $-71.4 * * * *$ & $-67.4^{* * *}$ & $\mathrm{X}$ & $\mathrm{x}$ & $\mathrm{X}$ & $\mathrm{x}$ & Yes & Yes & Yes \\
\hline & Sch. Spending per Pupil & $-55.5 * * *$ & $-53.3 * * *$ & $\mathrm{x}$ & $\mathrm{x}$ & $-0.0020 * * *$ & $-0.0018 * * *$ & Yes & Yes & Yes \\
\hline & Financial Literacy & $-71.0 * * *$ & $-67.2^{* * *}$ & $2.43^{*}$ & $-3.56^{* * *}$ & $-4.92 * *$ & -2.1 & Yes & Yes & Yes \\
\hline & Economic Literacy & $-72.5 * * *$ & $-68.6 * * *$ & -1.72 & $-4.54^{*}$ & 3.17 & 3.53 & Yes & Yes & Yes \\
\hline & Math Curr. Improvement & $-70.2 * * *$ & $-66.1^{* * *}$ & -1.36 & 0.71 & $-4.96 * *$ & $-5.21 * *$ & Yes & Yes & Yes \\
\hline \multirow{5}{*}{ Has Credit Card } & None (Benchmark) & $-0.070 * * *$ & $-0.11 * * *$ & $\mathrm{x}$ & $\mathrm{x}$ & $\mathrm{x}$ & $\mathrm{x}$ & Yes & Yes & Yes \\
\hline & Sch. Spending per Pupil & $-0.12 * * *$ & $-0.16 * * *$ & $\mathrm{x}$ & $\mathrm{x}$ & $0.0000069 * * *$ & $0.0000064^{* * *}$ & Yes & Yes & Yes \\
\hline & Financial Literacy & $-0.070 * * *$ & $-0.11 * * *$ & $-0.012 * *$ & -0.0015 & $0.0081^{*}$ & 0.0049 & Yes & Yes & Yes \\
\hline & Economic Literacy & $-0.066^{* * *}$ & $-0.10 * * *$ & $0.041^{* * *}$ & $0.024 * * *$ & -0.011 & -0.016 & Yes & Yes & Yes \\
\hline & Math Curr. Improvement & $-0.068 * * *$ & $-0.11^{* * *}$ & 0.0056 & $-0.020 * * *$ & -0.0073 & 0.00026 & Yes & Yes & Yes \\
\hline
\end{tabular}

Note: Results using data from the New York Federal Reserve Bank Consumer Credit Panel/Equifax dataset and educational policy variables from Brown et al. (2016). 
Table 12: Educational Policies and Strength of Intergenerational Linkages between Child Credit Outcomes and Parental Equifax Risk Score

\begin{tabular}{|c|c|c|c|c|c|c|c|c|c|c|}
\hline \multirow{2}{*}{ Child Outcome } & \multirow{2}{*}{ Covariate Specification } & \multicolumn{2}{|c|}{$\begin{array}{c}\text { Coef. On Parent Equifax Risk } \\
\text { Score }\end{array}$} & \multicolumn{2}{|c|}{$\begin{array}{l}\text { Coef. On Educational } \\
\text { Policy }\end{array}$} & \multicolumn{2}{|c|}{$\begin{array}{c}\text { Coef. On (Parent Equifax Risk Score) * } \\
\text { Educational Policy }\end{array}$} & \multicolumn{3}{|c|}{ Other Controls } \\
\hline & & $\begin{array}{l}\text { 5-Year } \\
\text { Horizon }\end{array}$ & $\begin{array}{l}\text { 10-Year } \\
\text { Horizon }\end{array}$ & $\begin{array}{l}\text { 5-Year } \\
\text { Horizon }\end{array}$ & $\begin{array}{l}\text { 10-Year } \\
\text { Horizon }\end{array}$ & 5-Year Horizon & 10-Year Horizon & Cohort & $\begin{array}{l}\text { Zip } \\
\text { Code }\end{array}$ & $\begin{array}{l}\text { Parent } \\
\text { Age }\end{array}$ \\
\hline \multirow{5}{*}{ Delinquency } & None (Benchmark) & $-0.00086 * * *$ & $-0.00046 * * *$ & $\mathrm{x}$ & $\mathrm{x}$ & $\mathrm{x}$ & $\mathrm{x}$ & Yes & Yes & Yes \\
\hline & Sch. Spending per Pupil & $-0.00064 * * *$ & $-0.00030 * * *$ & $\mathrm{x}$ & $\mathrm{x}$ & $-0.000000029 * * *$ & $-0.000000021^{* *}$ & Yes & Yes & Yes \\
\hline & Financial Literacy & $-0.00086^{* * *}$ & $-0.00046 * * *$ & 0.017 & 0.027 & -0.000028 & -0.000026 & Yes & Yes & Yes \\
\hline & Economic Literacy & $-0.00089 * * *$ & $-0.00049 * * *$ & -0.028 & 0.0037 & $0.000063^{* *}$ & $0.000058 * * *$ & Yes & Yes & Yes \\
\hline & Math Curr. Improvement & $-0.00086 * * *$ & $-0.00045 * * *$ & 0.019 & $0.027 *$ & -0.000035 & $-0.000042^{*}$ & Yes & Yes & Yes \\
\hline \multirow{5}{*}{ Homeownership } & None (Benchmark) & $0.00012 * * *$ & $0.00062 * * *$ & $\mathrm{x}$ & $\mathrm{x}$ & $\mathrm{x}$ & $\mathrm{x}$ & Yes & Yes & Yes \\
\hline & Sch. Spending per Pupil & $0.00038 * * *$ & $0.00095 * * *$ & $\mathrm{x}$ & $\mathrm{x}$ & $-0.000000033^{* * *}$ & $-0.000000042 * * *$ & Yes & Yes & Yes \\
\hline & Financial Literacy & $0.00013^{* * *}$ & $0.00062 * * *$ & $0.050 * * *$ & 0.048 & $-0.000067 * *$ & -0.000071 & Yes & Yes & Yes \\
\hline & Economic Literacy & $0.00012 * * *$ & $0.00063^{* * *}$ & -0.011 & 0.026 & 0.000013 & -0.00004 & Yes & Yes & Yes \\
\hline & Math Curr. Improvement & $0.00011^{* * *}$ & $0.00059 * * *$ & -0.036 & $-0.079 * *$ & 0.000037 & $0.00010 *$ & Yes & Yes & Yes \\
\hline \multirow{5}{*}{$\begin{array}{l}\text { Date T Equifax } \\
\text { Risk Score }\end{array}$} & None (Benchmark) & $0.38 * * *$ & $0.34 * * *$ & $\mathrm{x}$ & $\mathrm{x}$ & $\mathrm{x}$ & $\mathrm{x}$ & Yes & Yes & Yes \\
\hline & Sch. Spending per Pupil & $0.31 * * *$ & $0.30 * * *$ & $\mathrm{x}$ & $\mathrm{x}$ & $0.0000084 * * *$ & $0.0000061^{*}$ & Yes & Yes & Yes \\
\hline & Financial Literacy & $0.37 * * *$ & $0.34 * * *$ & $-17.2^{* * *}$ & $-12.3^{* *}$ & $0.026 * * *$ & $0.011^{*}$ & Yes & Yes & Yes \\
\hline & Economic Literacy & $0.38 * * *$ & $0.35 * * *$ & $14.0 * *$ & 9.88 & $-0.021^{* *}$ & $-0.020 *$ & Yes & Yes & Yes \\
\hline & Math Curr. Improvement & $0.37 * * *$ & $0.34^{* * *}$ & $-20.6 * * *$ & $-20.5 * * *$ & $0.026 * * *$ & $0.026 * * *$ & Yes & Yes & Yes \\
\hline \multirow{5}{*}{ Has Credit Card } & None (Benchmark) & $0.00050^{* * *}$ & $0.00073 * * *$ & $\mathrm{x}$ & $\mathrm{x}$ & $\mathrm{x}$ & $\mathrm{x}$ & Yes & Yes & Yes \\
\hline & Sch. Spending per Pupil & $0.00094 * * *$ & $0.0011^{* * *}$ & $\mathrm{x}$ & $\mathrm{x}$ & $-0.000000057 * * *$ & $-0.000000043^{* * *}$ & Yes & Yes & Yes \\
\hline & Financial Literacy & $0.00051^{* * *}$ & $0.00073 * * *$ & $0.062 * *$ & 0.032 & $-0.00010 * * *$ & -0.000043 & Yes & Yes & Yes \\
\hline & Economic Literacy & $0.00048^{* * *}$ & $0.00071^{* * *}$ & 0.00024 & -0.038 & 0.000047 & 0.000051 & Yes & Yes & Yes \\
\hline & Math Curr. Improvement & $0.00049 * * *$ & $0.00072 * * *$ & -0.033 & $-0.050 *$ & 0.000055 & 0.000034 & Yes & Yes & Yes \\
\hline
\end{tabular}

Note: Results using data from the New York Federal Reserve Bank Consumer Credit Panel/Equifax dataset and educational policy variables from Brown et al. (2016). 
Table 13: Parental Equifax Risk Score Conditional on Predicted Income Quintile, 2005-2008 CCP Sample with CRISM

\begin{tabular}{|ccccccc|}
\hline Quintile & Mean & Std. Dev. & 25th \% & Median & 75th \% & Obs. \\
\hline \hline Lowest & 624 & 104 & 555 & 629 & 703 & 85,760 \\
2 & 707 & 89 & 656 & 727 & 777 & 91,621 \\
3 & 738 & 75 & 701 & 758 & 793 & 84,911 \\
4 & 755 & 67 & 724 & 772 & 804 & 83,324 \\
Highest & 781 & 53 & 759 & 797 & 820 & 81,690 \\
\hline
\end{tabular}

Note: Results using data from the New York Federal Reserve Bank Consumer Credit Panel/Equifax and Equifax Credit Risk Insight Servicing McDash (CRISM). 
Table 14: Parental Equifax Risk Score and Child Outcomes at $t_{0}+5$, Controlling for Parental Income

\begin{tabular}{|l|c|c|cc|c|}
\hline \multicolumn{1}{|c|}{ Child Outcome } & $\begin{array}{c}\text { Coef. On } \\
\text { Parent Equifax } \\
\text { Risk Score }\end{array}$ & $\begin{array}{c}\text { Coef. On Family's } \\
\text { CRISM Income }\end{array}$ & \multicolumn{2}{|c|}{$\begin{array}{c}\text { Fixed effects } \\
\text { controls }\end{array}$} & $\mathrm{R}^{2}$ \\
\hline \hline Bankruptcy & $-0.000018^{* * *}$ & - & Yes & Yes & $2.4 \%$ \\
\hline Delinquency & $-0.000014^{* * *}$ & $-0.000000018^{* * *}$ & Yes & Yes & $2.4 \%$ \\
\hline Homeowner & $-0.00079^{* * *}$ & - & Yes & Yes & $6.9 \%$ \\
\hline Other Serious Default & $-0.00072^{* * *}$ & $-0.00000039^{* * *}$ & Yes & Yes & $7.0 \%$ \\
(Ex. Foreclosure and & $0.000082^{* * *}$ & - & Yes & Yes & $4.4 \%$ \\
Bankruptcy) & $0.000089^{* * *}$ & $-0.000000032^{* * *}$ & Yes & Yes & $4.4 \%$ \\
\hline Average Equifax Risk & $-0.0014^{* * *}$ & - & Yes & Yes & $17.0 \%$ \\
Score & $0.0013^{* * *}$ & $-0.00000081^{* * *}$ & Yes & Yes & $17.0 \%$ \\
\hline Date T Equifax Risk & $0.33^{* * *}$ & - & Yes & Yes & $31.0 \%$ \\
Score & $0.36^{* * *}$ & $0.00018^{* * *}$ & Yes & Yes & $32.0 \%$ \\
\hline Has Credit Card & $0.00031^{* * *}$ & - & Yes & Yes & $23.0 \%$ \\
& $0.00029 * * *$ & $0.00000012^{* * *}$ & Yes & Yes & $5.2 \%$ \\
\hline
\end{tabular}

Notes: 1) Sample of parents in 2005-2008 rather than benchmark sample. 2) Results using data from the New York Federal Reserve Bank Consumer Credit Panel/Equifax and Equifax Credit Risk Insight Servicing McDash (CRISM) 
Table 15: Intergenerational Linkages in Household Credit with and without Controls for Family Heterogeneity

\begin{tabular}{|c|c|c|c|c|c|}
\hline & \multicolumn{5}{|c|}{ Parental Equifax Risk Score } \\
\hline Child Outcome & $\begin{array}{l}\text { No controls for } \\
\text { family heterogeneity }\end{array}$ & $\begin{array}{l}\text { With controls for } \\
\text { family heterogeneity }\end{array}$ & $\begin{array}{c}\text { Cohort } \\
\text { Fixed } \\
\text { Effects }\end{array}$ & $\begin{array}{l}\text { Zip Code } \\
\text { Fixed } \\
\text { Effects }\end{array}$ & $\mathrm{N}$ \\
\hline Credit Constrained & $-0.0012 * * *$ & -0.0000021 & Yes & Yes & 31,510 \\
\hline Average Equifax Risk Score & $0.35^{* * *}$ & $0.022 *$ & Yes & Yes & 35,438 \\
\hline \multirow[t]{3}{*}{ Date T Equifax Risk Score } & $0.37 * * *$ & -0.010 & Yes & Yes & 35,011 \\
\hline & \multicolumn{5}{|c|}{ Parental Credit Constraints } \\
\hline & $\begin{array}{l}\text { No controls for } \\
\text { family heterogeneity }\end{array}$ & $\begin{array}{l}\text { With controls for } \\
\text { family heterogeneity }\end{array}$ & $\begin{array}{c}\text { Cohort } \\
\text { Fixed } \\
\text { Effects }\end{array}$ & $\begin{array}{l}\text { Zip Code } \\
\text { Fixed } \\
\text { Effects }\end{array}$ & $\mathrm{N}$ \\
\hline Credit Constrained & $0.27 * * *$ & -0.005 & Yes & Yes & 28,220 \\
\hline Average Equifax Risk Score & $-59.9 * * *$ & -2.450 & Yes & Yes & 31,760 \\
\hline Date T Equifax Risk Score & $-67.5 * * *$ & 0.470 & Yes & Yes & 31,453 \\
\hline
\end{tabular}

Notes: 1) Results using data from the New York Federal Reserve Bank Consumer Credit Panel/Equifax dataset. 2) Regressions in this table are run on the sibling sample, i.e., the subsample of children who have at least one sibling in our data. 3) Column (2) shows the coefficient estimates from the regression of the child outcome on the parental credit attribute as described in eq. (1). Each regression in column (2) also controls for parental age in levels. 4) Column (3) shows the coefficient estimates from the regression of the demeaned child outcome on the demeaned parental credit attribute as described in eq. (2). Each regression in column (3) also controls for demeaned parental age. Demeaned variables subtract off within-family mean for that variable. 5) Table presents results for the 5-year horizon; results for the 10-year horizon are similar and available upon request. 
Table 16: Presence of Student Loan Within 5 Years, With and Without Parent Fixed Effects Panel A: Parent Constrained

\begin{tabular}{|c|cccccr|}
\hline \multirow{2}{*}{ Child Outcome } & $\begin{array}{c}\text { Parental } \\
\text { Income } \\
\text { Quintile }\end{array}$ & $\begin{array}{c}\text { Coef. On Parent } \\
\text { Constrained }\end{array}$ & $\begin{array}{c}\text { Cohort } \\
\text { Fixed } \\
\text { Effects }\end{array}$ & $\begin{array}{c}\text { State } \\
\text { Fixed } \\
\text { Effects }\end{array}$ & $\begin{array}{c}\text { Parent Fixed } \\
\text { Effects }\end{array}$ & N \\
\hline \hline \multirow{2}{*}{ Student Loan } & Lowest & 0.027 & Yes & Yes & No & 3,235 \\
& & -0.047 & Yes & Yes & Yes & 3,235 \\
Student Loan & 2 & $0.057^{* * *}$ & Yes & Yes & No & 3,559 \\
& & 0.055 & Yes & Yes & Yes & 3,559 \\
Student Loan & \multirow{2}{*}{3} & $0.062^{* *}$ & Yes & Yes & No & 3,778 \\
& & -0.028 & Yes & Yes & Yes & 3,778 \\
Student Loan & \multirow{2}{*}{4} & $0.12^{* * *}$ & Yes & Yes & No & 3,910 \\
& & -0.033 & Yes & Yes & Yes & 3,910 \\
Student Loan & \multirow{2}{*}{ Highest } & $0.20^{* * *}$ & Yes & Yes & No & 3,810 \\
& & 0.062 & Yes & Yes & Yes & 3,810 \\
\hline
\end{tabular}

Panel B: Parent Equifax Risk Score

\begin{tabular}{|c|cccccr|}
\hline \multirow{2}{*}{ Child Outcome } & $\begin{array}{c}\text { Parental } \\
\text { Income } \\
\text { Quintile }\end{array}$ & $\begin{array}{c}\text { Coef. On Parent } \\
\text { Riskscore }\end{array}$ & $\begin{array}{c}\text { Cohort } \\
\text { Fixed } \\
\text { Effects }\end{array}$ & $\begin{array}{c}\text { State } \\
\text { Fixed } \\
\text { Effects }\end{array}$ & $\begin{array}{c}\text { Parent Fixed } \\
\text { Effects }\end{array}$ & N \\
\hline \hline \multirow{2}{*}{ Student Loan } & Lowest & 0.000037 & Yes & Yes & No & 3,906 \\
& & 0.00041 & Yes & Yes & Yes & 3,906 \\
Student Loan & 2 & -0.000022 & Yes & Yes & No & 3,920 \\
& & -0.00029 & Yes & Yes & Yes & 3,920 \\
Student Loan & \multirow{2}{*}{3} & $-0.00018^{*}$ & Yes & Yes & No & 3,883 \\
& & 0.00034 & Yes & Yes & Yes & 3,883 \\
Student Loan & \multirow{2}{*}{4} & $-0.00049^{* * *}$ & Yes & Yes & No & 3,930 \\
& & 0.000039 & Yes & Yes & Yes & 3,930 \\
Student Loan & \multirow{2}{*}{ Highest } & $-0.0012^{* * *}$ & Yes & Yes & No & 3,825 \\
& & $-0.00053^{*}$ & Yes & Yes & Yes & 3,825 \\
\hline
\end{tabular}

Notes: 1) Sample is children of parents from 2005-2008 CRISM sample. 2) Parental Income Quintile is based on predicted parental income. 3) Due to the small sample size, we include state rather than zip code fixed effects in these specifications. 4) Results using data from the New York Federal Reserve Bank Consumer Credit Panel/Equifax and Equifax Credit Risk Insight Servicing McDash (CRISM). 


\section{Appendix A. Variables Definitions}

The child credit outcomes that we study are

1. An indicator for having a credit card that is a dummy variable that takes a value of 1 if the child has a credit card between age 19 and 24 for the short horizon sample and between age 25 and 29 for the long horizon sample.

2. A dummy variable that takes value 1 if the child has a mortgage between age 19 and 24 for the short horizon sample and between 19 and 29 for the long horizon sample.

3. A dummy variable that takes value 1 if the child has a bankruptcy flag on his or her credit record between age 19 and 24 for the short horizon sample and between age 25 and 29 for the long horizon sample.

4. A dummy variable that takes value 1 if the child has an account 90DPD or greater default (excluding bankruptcy and foreclosure) on his or her credit record between age 19 and 24 for the short horizon sample and between age 25 and 29 for the long horizon sample.

5. A dummy variable that takes value 1 if the child has an account 30DPD or 60DPD on his or her credit record between age 19 and 24 for the short horizon sample and between age 25 and 29 for the long horizon sample.

6. The average Equifax Risk Score for the child between age 19 and 24 for the short horizon sample and between age 25 and 29 for the long horizon sample.

7. The child's Equifax Risk Score at the age 24 for the short horizon sample and at the age 29 for the long horizon sample.

The parental attributes that we study are

1. An indicator for parents' bankruptcy that takes value 1 if a parent has any account in bankruptcy and 0 otherwise, measured when the child is 19 years old.

2. An indicator for parents' foreclosure that takes value 1 if a parent has a foreclosure and 0 otherwise, measured when the child is 19 years old.

3. An indicator for parents' serious default that takes value 1 if a parent has any account 90DPD or greater default (excluding bankruptcy and foreclosure) and 0 otherwise, measured when the child is 19 years old.

4. An indicator for parents' delinquency that takes value 1 if a parent has any account 30DPD or 60DPD and 0 otherwise, measured when the child is 19 years old.

5. The degree of parents being credit constrained is the ratio of credit balance to card limit, measured when the child is 19 years old. It is the maximum credit balance as a percentage of the combined credit limit available for use at time to of the two parents if there are two.

6. Parents' credit Equifax Risk Score, measured when the child is 19 years old and the average if there are two parents in the household.

Parents' age when the child is 19 years old, measured as the average age if there are two parents in the household. 
Table A1: Summary Statistics for 5-year subsample of the original 10-year sample

\begin{tabular}{|lcccccccc|}
\hline & Mean & Std. Dev. & Min & 25th \% & Median & 75th \% & Max & Obs. \\
\hline Child Forms Household & 0.55 & 0.50 & 0 & 0 & 1 & 1 & 1 & 417,601 \\
Child Forms Household First Age & 21.5 & 1.4 & 20 & 20 & 21 & 23 & 24 & 228,739 \\
Child Has Credit Card & 0.84 & 0.37 & 0 & 1 & 1 & 1 & 1 & 417,601 \\
Child Has Credit Card First Age & 19.7 & 1.5 & 15 & 19 & 19 & 20 & 24 & 350,481 \\
Child Homeowner & 0.11 & 0.31 & 0 & 0 & 0 & 0 & 1 & 417,601 \\
Child Homeowner First Age & 22.5 & 1.6 & 15 & 22 & 23 & 24 & 24 & 46,247 \\
Child Bankrupt & 0.019 & 0.136 & 0 & 0 & 0 & 0 & 1 & 417,601 \\
Child Foreclosure & 0.066 & 0.249 & 0 & 0 & 0 & 0 & 1 & 417,601 \\
Child Other Serious Default & 0.33 & 0.47 & 0 & 0 & 0 & 1 & 1 & 399,357 \\
Child Delinquency & 0.25 & 0.44 & 0 & 0 & 0 & 1 & 1 & 399,357 \\
Child Equifax Risk Score Average & 630.6 & 77.7 & 295 & 566.8 & 645.7 & 695 & 827 & 408,162 \\
Child Equifax Risk Score End & 633.5 & 99.0 & 288 & 561 & 644 & 720 & 834 & 364,045 \\
Child Credit Constrained & 0.632 & 0.339 & 0 & 0.337 & 0.739 & 0.945 & 1 & 354,460 \\
\hline
\end{tabular}

Note: Authors' calculations using the New York Federal Reserve Bank Consumer Credit Panel/Equifax dataset. 
Table A2: Benchmark Regressions of the Intergenerational Linkages between Child Credit Outcomes and Parental Credit Constraints, with an Indicator for Cosigned Credit Cards

\begin{tabular}{|c|c|c|c|c|c|c|c|c|c|c|c|c|}
\hline \multirow[t]{2}{*}{ Child Outcome } & \multicolumn{2}{|c|}{$\begin{array}{l}\text { Coef. On Parent } \\
\text { Constrained }\end{array}$} & \multicolumn{2}{|c|}{ Coef. On Parent Age } & \multicolumn{2}{|c|}{$\begin{array}{l}\text { Coef. On Indicator of } \\
\text { Child Cosign Credit } \\
\text { Card }\end{array}$} & \multicolumn{2}{|c|}{$\begin{array}{l}\text { Coef. On (Indicator of } \\
\text { Child Cosign Credit } \\
\text { Card)* (Parent } \\
\text { Constrained) }\end{array}$} & \multicolumn{2}{|c|}{ Fixed effects } & \multicolumn{2}{|c|}{ Adjusted $\mathrm{R}^{2}$} \\
\hline & $\begin{array}{l}\text { 5-Year } \\
\text { Horizon }\end{array}$ & $\begin{array}{l}\text { 10-Year } \\
\text { Horizon }\end{array}$ & $\begin{array}{l}\text { 5-Year } \\
\text { Horizon }\end{array}$ & $\begin{array}{l}\text { 10-Year } \\
\text { Horizon }\end{array}$ & $\begin{array}{l}\text { 5-Year } \\
\text { Horizon }\end{array}$ & $\begin{array}{l}\text { 10-Year } \\
\text { Horizon }\end{array}$ & $\begin{array}{l}\text { 5-Year } \\
\text { Horizon }\end{array}$ & $\begin{array}{l}10 \text {-Year } \\
\text { Horizon }\end{array}$ & Cohort & $\begin{array}{l}\text { Zip } \\
\text { Code }\end{array}$ & $\begin{array}{l}\text { 5- } \\
\text { Year }\end{array}$ & $\begin{array}{l}10- \\
\text { Year }\end{array}$ \\
\hline \multirow{2}{*}{ Bankruptcy } & $0.014 * * *$ & $0.031^{* * *}$ & -0.0000021 & $-0.00022 * *$ & -0.000078 & $-0.010 * * *$ & $0.018 * * *$ & $0.020 * * *$ & Yes & No & $0.54 \%$ & $0.65 \%$ \\
\hline & $0.012 * * *$ & $0.025^{* * *}$ & $0.000061^{*}$ & -0.000020 & -0.00056 & $-0.012 * * *$ & $0.018 * * *$ & $0.021 * * *$ & Yes & Yes & $1.7 \%$ & $2.5 \%$ \\
\hline \multirow{2}{*}{ Delinquency } & $0.20 * * *$ & $0.12 * * *$ & $-0.00056 * * *$ & $-0.00043 * *$ & $-0.029 * * *$ & $-0.025 * * *$ & $0.032 * * *$ & $0.019 * *$ & Yes & No & $2.8 \%$ & $1.6 \%$ \\
\hline & $0.16^{* * *}$ & $0.10 * * *$ & $-0.00038 * *$ & $-0.00025^{*}$ & $-0.027 * * *$ & $-0.021 * * *$ & $0.033^{* * *}$ & $0.023 * * *$ & Yes & Yes & $4.6 \%$ & $2.9 \%$ \\
\hline \multirow{2}{*}{ Homeowner } & $-0.021 * * *$ & $-0.13 * * *$ & $-0.0013^{* * *}$ & $-0.0028 * * *$ & $0.098 * * *$ & $0.24 * * *$ & $0.034 * * *$ & $0.053 * * *$ & Yes & No & $2 \%$ & $5.7 \%$ \\
\hline & $-0.021 * * *$ & $-0.11 * * *$ & $-0.00077 * * *$ & $-0.0019 * * *$ & $0.092 * * *$ & $0.22 * * *$ & $0.032 * * *$ & $0.052 * * *$ & Yes & Yes & $4.7 \%$ & $8.2 \%$ \\
\hline \multirow{2}{*}{$\begin{array}{l}\text { Other Serious } \\
\text { Default (Ex. } \\
\text { Foreclos. and } \\
\text { Bankruptcy) }\end{array}$} & $0.32 * * *$ & $0.31^{* * *}$ & -0.0000070 & -0.00043 & $-0.069 * * *$ & $-0.095 * * *$ & $-0.023 * * *$ & $-0.086 * * *$ & Yes & No & $6.5 \%$ & $6.1 \%$ \\
\hline & $0.26^{* * *}$ & $0.24 * * *$ & 0.000025 & -0.00023 & $-0.064 * * *$ & $-0.086 * * *$ & $-0.018^{* *}$ & $-0.073 * * *$ & Yes & Yes & $12 \%$ & $11 \%$ \\
\hline \multirow{2}{*}{$\begin{array}{l}\text { Average } \\
\text { Equifax Risk } \\
\text { Score }\end{array}$} & $-77.1 * * *$ & $-84.4 * * *$ & 0.057 & 0.079 & $21.1 * * *$ & $30.5^{* * *}$ & $-5.81 * * *$ & $12.4^{* * *}$ & Yes & No & $14 \%$ & $12 \%$ \\
\hline & $-62.8 * * *$ & $-68.2^{* * *}$ & 0.010 & 0.020 & $20.0 * * *$ & $28.9 * * *$ & $-6.89 * * *$ & $8.10^{* * *}$ & Yes & Yes & $23 \%$ & $19 \%$ \\
\hline \multirow{2}{*}{$\begin{array}{l}\text { Date T Equifax } \\
\text { Risk Score }\end{array}$} & $-85.5^{* * *}$ & $-83.3 * * *$ & $0.15^{* *}$ & 0.062 & $21.1^{* * *}$ & $28.7^{* * *}$ & $-3.99 * *$ & $12.4^{* * *}$ & Yes & No & $10 \%$ & $9.5 \%$ \\
\hline & $-69.2 * * *$ & $-66.8 * * *$ & $0.077 * *$ & 0.0013 & $19.8 * * *$ & $27.0 * * *$ & $-5.31 * * *$ & $8.56^{* * *}$ & Yes & Yes & $17 \%$ & $16 \%$ \\
\hline \multirow{2}{*}{ Has Credit Card } & $-0.094 * * *$ & $-0.15^{* * *}$ & $-0.00037 * *$ & -0.00027 & $0.10^{* * *}$ & $0.11^{* * *}$ & $0.062 * * *$ & $0.13 * * *$ & Yes & No & $2.7 \%$ & $4.4 \%$ \\
\hline & $-0.069 * * *$ & $-0.12 * * *$ & $-0.00055^{* * *}$ & $-0.00049 * * *$ & $0.099 * * *$ & $0.11^{* * *}$ & $0.058 * * *$ & $0.11^{* * *}$ & Yes & Yes & $6.4 \%$ & $8 \%$ \\
\hline
\end{tabular}

Note: Results using data from the New York Federal Reserve Bank Consumer Credit Panel/Equifax dataset. 
Table A3: Benchmark Regressions of the Intergenerational Linkages between Child Credit Outcomes and Parental Serious Default, with an Indicator for Cosigned Credit Cards

\begin{tabular}{|c|c|c|c|c|c|c|c|c|c|c|c|c|}
\hline \multirow[t]{2}{*}{ Child Outcome } & \multicolumn{2}{|c|}{$\begin{array}{l}\text { Coef. On Parent } \\
\text { Serious Default }\end{array}$} & \multicolumn{2}{|c|}{ Coef. On Parent Age } & \multicolumn{2}{|c|}{$\begin{array}{l}\text { Coef. On Indicator of } \\
\text { Child Cosign Credit Card }\end{array}$} & \multicolumn{2}{|c|}{$\begin{array}{c}\text { Coef. On (Indicator of } \\
\text { Child Cosign Credit } \\
\text { Card) * (Parent Serious } \\
\text { Default) }\end{array}$} & \multicolumn{2}{|c|}{ Fixed effects } & \multicolumn{2}{|c|}{ Adjusted $\mathrm{R}^{2}$} \\
\hline & $\begin{array}{l}\text { 5-Year } \\
\text { Horizon }\end{array}$ & $\begin{array}{l}\text { 10-Year } \\
\text { Horizon }\end{array}$ & $\begin{array}{l}\text { 5-Year } \\
\text { Horizon }\end{array}$ & $\begin{array}{l}\text { 10-Year } \\
\text { Horizon }\end{array}$ & $\begin{array}{l}\text { 5-Year } \\
\text { Horizon }\end{array}$ & $\begin{array}{l}\text { 10-Year } \\
\text { Horizon }\end{array}$ & $\begin{array}{l}\text { 5-Year } \\
\text { Horizon }\end{array}$ & $\begin{array}{l}\text { 10-Year } \\
\text { Horizon }\end{array}$ & Cohort & $\begin{array}{l}\text { Zip } \\
\text { Code }\end{array}$ & $\begin{array}{l}\text { 5- } \\
\text { Year }\end{array}$ & $\begin{array}{l}10- \\
\text { Year }\end{array}$ \\
\hline \multirow{2}{*}{ Bankruptcy } & $0.013^{* * *}$ & $0.025^{* * *}$ & -0.000024 & $-0.00021 * * *$ & $0.0050 * * *$ & $-0.0050 * *$ & $0.016 * * *$ & $0.022 * * *$ & Yes & No & $0.58 \%$ & $0.65 \%$ \\
\hline & $0.011^{* * *}$ & $0.022^{* * *}$ & 0.000048 & -0.0000097 & $0.0045^{* * *}$ & $-0.0067 * * *$ & $0.016^{* * *}$ & $0.023 * * *$ & Yes & Yes & $1.6 \%$ & $2.6 \%$ \\
\hline \multirow{2}{*}{ Delinquency } & $0.13^{* * *}$ & $0.075^{* * *}$ & $-0.00097 * * *$ & $-0.00071^{* * *}$ & $-0.028 * * *$ & $-0.023 * * *$ & $0.039 * * *$ & $0.025 * * *$ & Yes & No & $2.1 \%$ & $1.1 \%$ \\
\hline & $0.11^{* * *}$ & $0.053^{* * *}$ & $-0.00071^{* * *}$ & $-0.00049 * * *$ & $-0.024 * * *$ & $-0.017 * * *$ & $0.038^{* * *}$ & $0.027 * * *$ & Yes & Yes & $3.9 \%$ & $2.4 \%$ \\
\hline \multirow{2}{*}{ Homeowner } & $-0.017 * * *$ & $-0.095 * * *$ & $-0.00085^{* * *}$ & $-0.0016^{* * *}$ & $0.11 * * *$ & $0.26^{* * *}$ & $0.021^{* * *}$ & $0.024^{* * *}$ & Yes & No & $2.1 \%$ & $5.9 \%$ \\
\hline & $-0.013 * * *$ & $-0.075 * * *$ & $-0.00038 * * *$ & $-0.00095 * * *$ & $0.11^{* * *}$ & $0.25^{* * *}$ & $0.020^{* * *}$ & $0.023^{* * *}$ & Yes & Yes & $4.6 \%$ & $8.3 \%$ \\
\hline \multirow{2}{*}{$\begin{array}{l}\text { Other Serious } \\
\text { Default (Ex. } \\
\text { Foreclos. and } \\
\text { Bankruptcy) }\end{array}$} & $0.29 * * *$ & $0.24 * * *$ & $-0.0010^{* * *}$ & $-0.0014 * * *$ & $-0.093 * * *$ & $012 * * *$ & 0.00076 & $-0.051 * * *$ & Yes & No & $7.8 \%$ & $6.1 \%$ \\
\hline & $0.23^{* * *}$ & $0.18^{* * *}$ & $-0.00084 * * *$ & $-0.00099 * * *$ & $-0.082 * * *$ & $-0.12^{* * *}$ & 0.0026 & $-0.043^{* * *}$ & Yes & Yes & $14 \%$ & $11 \%$ \\
\hline \multirow{2}{*}{$\begin{array}{l}\text { Average } \\
\text { Equifax Risk } \\
\text { Score }\end{array}$} & $-62.3^{* * *}$ & $-60.9 * * *$ & $0.31^{* * *}$ & $0.36^{* * *}$ & $24.0^{* * *}$ & $38.5^{* * *}$ & $-6.05 * * *$ & $6.61^{* * *}$ & Yes & No & $14 \%$ & $11 \%$ \\
\hline & -48.3 & $-45.6^{* * *}$ & $0.22 * * *$ & $0.25^{* * *}$ & $21.5^{* * *}$ & $34.6^{* * *}$ & $-6.62 * * *$ & $3.86^{* *}$ & Yes & Yes & $24 \%$ & $20 \%$ \\
\hline \multirow{2}{*}{$\begin{array}{l}\text { Date T Equifax } \\
\text { Risk Score }\end{array}$} & $-65.2 * * *$ & $-60.8 * * *$ & $0.41 * * *$ & $0.34 * * *$ & $24.6 * * *$ & $36.5^{* * *}$ & $-4.64 * *$ & $6.63 * * *$ & Yes & No & $9.4 \%$ & $8.7 \%$ \\
\hline & $-49.6^{* * *}$ & $-45.1 * * *$ & $0.30 * * *$ & $0.24 * * *$ & $21.7 * * *$ & $32.8^{* * *}$ & $-5.42 * * *$ & $3.75^{*}$ & Yes & Yes & $17 \%$ & $16 \%$ \\
\hline \multirow{2}{*}{ Has Credit Card } & $-0.092 * * *$ & $-0.14^{* * *}$ & $0.00036^{* * *}$ & $0.00049 * * *$ & $0.14^{* * *}$ & $0.17 * * *$ & $0.065^{* * *}$ & $0.11^{* * *}$ & Yes & No & $3.4 \%$ & $5.2 \%$ \\
\hline & $-0.065 * * *$ & $-0.10 * * *$ & 0.000095 & 0.00015 & $0.13^{* * *}$ & $0.16^{* * *}$ & $0.061^{* * *}$ & $0.10^{* * *}$ & Yes & Yes & $8.3 \%$ & $9.7 \%$ \\
\hline
\end{tabular}

Note: Results using data from the New York Federal Reserve Bank Consumer Credit Panel/Equifax dataset. 
Table A4: Benchmark Regressions of the Intergenerational Linkages between Child Credit Outcomes and Parental Equifax Risk Score, with an Indicator for Cosigned Credit Cards

\begin{tabular}{|c|c|c|c|c|c|c|c|c|c|c|c|c|}
\hline \multirow{2}{*}{$\begin{array}{l}\text { Child } \\
\text { Outcome }\end{array}$} & \multicolumn{2}{|c|}{$\begin{array}{l}\text { Coef. On Parent Equifax } \\
\text { Risk Score }\end{array}$} & \multicolumn{2}{|c|}{ Coef. On Parent Age } & \multicolumn{2}{|c|}{$\begin{array}{l}\text { Coef. On Indicator of } \\
\text { Child Cosign Credit } \\
\text { Card }\end{array}$} & \multicolumn{2}{|c|}{$\begin{array}{l}\text { Coef. On (Indicator of Child } \\
\text { Cosign Credit Card) }{ }^{*} \\
\text { (Parent Equifax Risk Score) }\end{array}$} & \multicolumn{2}{|c|}{ Fixed effects } & \multicolumn{2}{|c|}{ Adjusted $\mathrm{R}^{2}$} \\
\hline & $\begin{array}{l}\text { 5-Year } \\
\text { Horizon }\end{array}$ & $\begin{array}{l}10 \text {-Year } \\
\text { Horizon }\end{array}$ & $\begin{array}{l}\text { 5-Year } \\
\text { Horizon }\end{array}$ & $\begin{array}{l}\text { 10-Year } \\
\text { Horizon }\end{array}$ & $\begin{array}{l}\text { 5-Year } \\
\text { Horizon }\end{array}$ & $\begin{array}{l}\text { 10-Year } \\
\text { Horizon }\end{array}$ & $\begin{array}{l}\text { 5-Year } \\
\text { Horizon }\end{array}$ & $\begin{array}{l}\text { 10-Year } \\
\text { Horizon }\end{array}$ & Cohort & $\begin{array}{l}\text { Zip } \\
\text { Code }\end{array}$ & $\begin{array}{l}5- \\
\text { Year }\end{array}$ & $\begin{array}{l}10- \\
\text { Year }\end{array}$ \\
\hline \multirow{2}{*}{ Bankruptcy } & $-0.000062 * * *$ & $-0.00012 * * *$ & 0.000056 & -0.000003 & 0.017 & $0.087 * * *$ & -0.000097 & $-0.00012 * * *$ & Yes & No & $0.7 \%$ & $0.77 \%$ \\
\hline & $-0.000055^{* * *}$ & $-0.00011^{* * *}$ & $0.00012^{* * *}$ & 0.000089 & $0.074 * * *$ & $0.084 * * *$ & $-0.000095^{* * *}$ & $-0.00012^{* * *}$ & Yes & Yes & $1.7 \%$ & $2.6 \%$ \\
\hline \multirow{2}{*}{ Delinquency } & $-0.00094^{* * *}$ & $-0.00054^{* * *}$ & $0.00047^{* * *}$ & 0.00014 & $0.18 * * *$ & $0.12^{* * *}$ & $-0.00026 * * *$ & $-0.00019 * * *$ & Yes & No & $5.4 \%$ & $2.3 \%$ \\
\hline & $-0.00083^{* * *}$ & $-0.00043^{* * *}$ & $0.00052^{* * *}$ & 0.00017 & $0.17 * * *$ & $0.13^{* * *}$ & $-0.00025^{* * *}$ & $-0.00020 * * *$ & Yes & Yes & $6.3 \%$ & $3.2 \%$ \\
\hline \multirow{2}{*}{ Homeowner } & $0.000098 * * *$ & $0.00061^{* * *}$ & $-0.0011^{* * *}$ & $-0.0027 * * *$ & $0.24 * * *$ & $0.40 * * *$ & $-0.00019 * * *$ & $-0.00020 * * *$ & Yes & No & $2.1 \%$ & $6.9 \%$ \\
\hline & $0.00010 * * *$ & $0.00056^{* * *}$ & $-0.00061 * * *$ & $-0.0019 * * *$ & $0.23 * * *$ & $0.38 * * *$ & $-0.00017 * * *$ & $-0.00020 * * *$ & Yes & Yes & $4.6 \%$ & $9 \%$ \\
\hline \multirow{2}{*}{$\begin{array}{l}\text { Other Serious } \\
\text { Default (Ex. } \\
\text { Foreclosure } \\
\text { and } \\
\text { Bankruptcy) }\end{array}$} & $-0.0018 * * *$ & $-0.0016^{* * *}$ & $0.0017 * * *$ & $0.00097 * * *$ & $-0.11^{* * *}$ & $-0.36 * * *$ & 0.000065 & $0.00035^{* * *}$ & Yes & No & $16 \%$ & $12 \%$ \\
\hline & $-0.0016 * * *$ & $-0.0013 * * *$ & $0.0013 * * *$ & $0.00082 * * *$ & $-0.094 * * *$ & $-0.33 *$ & 0.000048 & $0.00031^{* * *}$ & Yes & Yes & $19 \%$ & $15 \%$ \\
\hline \multirow{2}{*}{$\begin{array}{l}\text { Average } \\
\text { Equifax Risk } \\
\text { Score }\end{array}$} & $0.41 * * *$ & $0.42^{* * *}$ & $-0.32 * * *$ & $-0.28 * * *$ & -5.82 & $60.5^{* * *}$ & $0.031 * * *$ & $-0.041^{* * *}$ & Yes & No & $31 \%$ & $22 \%$ \\
\hline & $0.35^{* * *}$ & $0.34^{* * *}$ & $-0.29 * * *$ & $-0.26 * * *$ & $-8.42^{*}$ & $50.6 * * *$ & $0.034 * * *$ & $-0.029 * * *$ & Yes & Yes & $35 \%$ & $26 \%$ \\
\hline \multirow{2}{*}{$\begin{array}{l}\text { Date T } \\
\text { Equifax Risk } \\
\text { Score }\end{array}$} & $* *$ & & -0.26 & -0.2 & 2 & 6 & 00 & $-0.043^{* * *}$ & Yes & No & $22 \%$ & $18 \%$ \\
\hline & $0.37 * * *$ & $0.34^{* * *}$ & $-0.24 * * *$ & $-0.25 * * *$ & -6.00 & $50.6^{* * *}$ & $0.030 * * *$ & $-0.031^{* * *}$ & Yes & Yes & $25 \%$ & $22 \%$ \\
\hline \multirow{2}{*}{$\begin{array}{l}\text { Has Credit } \\
\text { Card }\end{array}$} & $0.00067 * * *$ & $0.00096 * * *$ & $-0.00067 * * *$ & $-0.00088^{* * *}$ & $0.47 * * *$ & $0.70^{* * *}$ & $-0.00049 * * *$ & $-0.00077 * * *$ & Yes & No & $5.3 \%$ & $8.5 \%$ \\
\hline & $0.00051^{* * *}$ & $0.00076^{* * *}$ & $-0.00067 * * *$ & $-0.00090 * * *$ & $0.45^{* * *}$ & $0.67 * * *$ & $-0.00045^{* * *}$ & $-0.00072 * * *$ & Yes & Yes & $8.9 \%$ & $11 \%$ \\
\hline
\end{tabular}

Note: Results using data from the New York Federal Reserve Bank Consumer Credit Panel/Equifax dataset. 
Table A5. Educational Policies (Urban and Schmeiser, 2015) and Strength of Intergenerational Linkages between Child Credit Outcomes and Parental Credit Constraints

\begin{tabular}{|c|c|c|c|c|c|c|c|c|c|c|}
\hline \multirow{2}{*}{ Child Outcome } & \multirow{2}{*}{ Covariate Specification } & \multicolumn{2}{|c|}{$\begin{array}{l}\text { Coef. On Parent } \\
\text { Constrained }\end{array}$} & \multicolumn{2}{|c|}{$\begin{array}{c}\text { Coef. On (Parent } \\
\text { Constrained) } \\
\text { Educational Policy }\end{array}$} & \multicolumn{3}{|c|}{ Fixed effects } & \multicolumn{2}{|c|}{ Adjusted $\mathrm{R}^{2}$} \\
\hline & & $\begin{array}{l}\text { 5-Year } \\
\text { Horizon }\end{array}$ & $\begin{array}{l}\text { 10-Year } \\
\text { Horizon }\end{array}$ & $\begin{array}{l}\text { 5-Year } \\
\text { Horizon }\end{array}$ & $\begin{array}{l}\text { 10-Year } \\
\text { Horizon }\end{array}$ & Cohort & $\begin{array}{l}\text { Zip } \\
\text { Code }\end{array}$ & $\begin{array}{l}\text { Parent } \\
\text { Age }\end{array}$ & $\begin{array}{l}\text { 5-Year } \\
\text { Horizon }\end{array}$ & $\begin{array}{l}\text { 10-Year } \\
\text { Horizon }\end{array}$ \\
\hline \multirow{3}{*}{ Delinquency } & None (Benchmark) & $0.17 * * *$ & $0.11 * * *$ & $\mathrm{x}$ & $\mathrm{x}$ & Yes & Yes & Yes & $4.6 \%$ & $2.9 \%$ \\
\hline & Personal Finance & $0.17 * * *$ & $0.10^{* * *}$ & $0.0083^{* *}$ & $0.0076^{*}$ & Yes & Yes & Yes & $4.6 \%$ & $2.9 \%$ \\
\hline & Economic Education & $0.17 * * *$ & $0.11 * * *$ & -0.0069 & $-0.012 * *$ & Yes & Yes & Yes & $4.6 \%$ & $2.9 \%$ \\
\hline \multirow{3}{*}{ Homeownership } & None (Benchmark) & $-0.025 * * *$ & $-0.12 * * *$ & $\mathrm{x}$ & $\mathrm{x}$ & Yes & Yes & Yes & $3.1 \%$ & $4.5 \%$ \\
\hline & Personal Finance & $-0.027 * * *$ & $-0.12 * * *$ & $0.013^{* *}$ & 0.016 & Yes & Yes & Yes & $3.1 \%$ & $4.5 \%$ \\
\hline & Economic Education & $-0.027 * * *$ & $-0.13 * * *$ & 0.0071 & $0.018 *$ & Yes & Yes & Yes & $3.1 \%$ & $4.5 \%$ \\
\hline \multirow{3}{*}{ Date T Riskscore } & None (Benchmark) & $-71.4^{* * * *}$ & $-67.4 * * *$ & $\mathrm{x}$ & $\mathrm{x}$ & Yes & Yes & Yes & $16 \%$ & $15 \%$ \\
\hline & Personal Finance & $-70.5^{* * *}$ & $-66.8 * * *$ & $-5.61 * * *$ & $-3.72 * *$ & Yes & Yes & Yes & $16 \%$ & $15 \%$ \\
\hline & Economic Education & $-72.3^{* * *}$ & $-68.9 * * *$ & 2.36 & 4.05 & Yes & Yes & Yes & $16 \%$ & $15 \%$ \\
\hline \multirow{3}{*}{ Has Credit Card } & None (Benchmark) & $-0.070 * * *$ & $-0.11 * * *$ & $\mathrm{x}$ & $\mathrm{x}$ & Yes & Yes & Yes & $4.7 \%$ & $5.6 \%$ \\
\hline & Personal Finance & $-0.071 * * *$ & $-0.11 * * *$ & 0.0090 & $0.013 *$ & Yes & Yes & Yes & $4.7 \%$ & $5.6 \%$ \\
\hline & Economic Education & $-0.072 * * *$ & $-0.11 * * *$ & 0.0066 & 0.0060 & Yes & Yes & Yes & $4.7 \%$ & $5.6 \%$ \\
\hline
\end{tabular}

Note: Results using data from the New York Federal Reserve Bank Consumer Credit Panel/Equifax dataset and educational policy data from Urban and Schmeiser (2015). 
Table A6: Educational Policies (Urban and Schmeiser, 2015) and Strength of Intergenerational Linkages between Child Credit Outcomes and Parental Equifax Risk Score

\begin{tabular}{|c|c|c|c|c|c|c|c|c|c|c|}
\hline \multirow[t]{2}{*}{ Child Outcome } & \multirow{2}{*}{$\begin{array}{c}\text { Covariate } \\
\text { Specification }\end{array}$} & \multicolumn{2}{|c|}{$\begin{array}{c}\text { Coef. On Parent Equifax Risk } \\
\text { Score }\end{array}$} & \multicolumn{2}{|c|}{$\begin{array}{c}\text { Coef. On (Parent Equifax } \\
\text { Risk Score) * Educational } \\
\text { Policy }\end{array}$} & \multicolumn{3}{|c|}{ Controls } & \multicolumn{2}{|c|}{ Adjusted $\mathrm{R}^{2}$} \\
\hline & & $\begin{array}{l}\text { 5-Year } \\
\text { Horizon }\end{array}$ & $\begin{array}{l}\text { 10-Year } \\
\text { Horizon }\end{array}$ & $\begin{array}{l}\text { 5-Year } \\
\text { Horizon }\end{array}$ & $\begin{array}{l}\text { 10-Year } \\
\text { Horizon }\end{array}$ & Cohort & $\begin{array}{l}\text { Zip } \\
\text { Code }\end{array}$ & $\begin{array}{l}\text { Parent } \\
\text { Age }\end{array}$ & $\begin{array}{l}\text { 5-Year } \\
\text { Horizon }\end{array}$ & $\begin{array}{l}10 \text {-Year } \\
\text { Horizon }\end{array}$ \\
\hline \multirow{3}{*}{ Delinquency } & None (Benchmark) & $-0.00086 * * *$ & $-0.00046^{* * *}$ & $\mathrm{x}$ & $\mathrm{x}$ & Yes & Yes & Yes & $6.3 \%$ & $3.1 \%$ \\
\hline & Personal Finance & $-0.00086 * * *$ & $-0.00046^{* * *}$ & $-0.000034^{* * *}$ & -0.0000023 & Yes & Yes & Yes & $6.3 \%$ & $3.1 \%$ \\
\hline & Economic Education & $-0.00086 * * *$ & $-0.00046^{* * *}$ & -0.0000074 & -0.0000039 & Yes & Yes & Yes & $6.3 \%$ & $3.1 \%$ \\
\hline \multirow{3}{*}{ Homeownership } & None (Benchmark) & $0.00012^{* * *}$ & $0.00062 * * *$ & $\mathrm{x}$ & $\mathrm{x}$ & Yes & Yes & Yes & $3 \%$ & $5.4 \%$ \\
\hline & Personal Finance & $0.00013^{* * *}$ & $0.00062 * * *$ & $-0.000040^{* *}$ & -0.000042 & Yes & Yes & Yes & $3 \%$ & $5.4 \%$ \\
\hline & Economic Education & $0.00012^{* * *}$ & $0.00063 * * *$ & -0.000011 & $-0.000032 *$ & Yes & Yes & Yes & $3 \%$ & $5.4 \%$ \\
\hline \multirow{3}{*}{$\begin{array}{l}\text { Date T Equifax } \\
\text { Risk Score }\end{array}$} & None (Benchmark) & $0.38 * * *$ & $0.34 * * *$ & $\mathrm{x}$ & $\mathrm{x}$ & Yes & Yes & Yes & $25 \%$ & $21 \%$ \\
\hline & Personal Finance & $0.38 * * *$ & $0.34 * * *$ & 0.0062 & 0.0032 & Yes & Yes & Yes & $25 \%$ & $21 \%$ \\
\hline & Economic Education & $0.38 * * *$ & $0.34 * * *$ & -0.0013 & -0.0041 & Yes & Yes & Yes & $25 \%$ & $21 \%$ \\
\hline \multirow{3}{*}{ Has Credit Card } & None (Benchmark) & $0.00050 * * *$ & $0.00073^{* * *}$ & $\mathrm{x}$ & $\mathrm{x}$ & Yes & Yes & Yes & $7.1 \%$ & $8.8 \%$ \\
\hline & Personal Finance & $0.00051^{* * *}$ & $0.00073^{* * *}$ & -0.000050 & -0.000027 & Yes & Yes & Yes & $7.1 \%$ & $8.8 \%$ \\
\hline & Economic Education & $0.00051^{* * *}$ & $0.00074 * * *$ & $-0.000033^{*}$ & -0.000026 & Yes & Yes & Yes & $7.1 \%$ & $8.8 \%$ \\
\hline
\end{tabular}

Note: Results using data from the New York Federal Reserve Bank Consumer Credit Panel/Equifax dataset and educational policy data from Urban and Schmeiser (2015). 
Table A7. Sibling Age Differences (19 year olds)

\begin{tabular}{|lcccccccc|}
\hline & Mean & Std. Dev. & Min & 25th \% & Median & 75th \% & Max & Obs. \\
\hline \hline 5 Yr Horizon Sample & 1.96 & 0.92 & 0 & 1 & 2 & 3 & 4 & 36,592 \\
10 Yr Horizon Sample & 1.92 & 0.92 & 0 & 1 & 2 & 2 & 4 & 16,943 \\
\hline
\end{tabular}

Notes: 1) Results using data from the New York Federal Reserve Bank Consumer Credit Panel/Equifax dataset. 2) The summary statistics are from the sibling sample, i.e., the subsample of children who have at least one sibling in our data. 
Table A8: Parental Equifax Risk Score at t0 and Child Outcomes, horizons from t0+1 to t0+10

\begin{tabular}{|c|c|c|c|c|c|}
\hline $\begin{array}{l}\text { Horizon } \\
\text { (date T) }\end{array}$ & & $\begin{array}{l}\text { Child's Date T } \\
\text { Bankruptcy }\end{array}$ & $\begin{array}{l}\text { Child's Date T } \\
\text { Delinquency }\end{array}$ & $\begin{array}{l}\text { Child's Date T Other } \\
\text { Serious Default (Ex. } \\
\text { Foreclosure and } \\
\text { Bankruptcy) }\end{array}$ & $\begin{array}{l}\text { Child's Date T } \\
\text { Equifax Risk } \\
\text { Score }\end{array}$ \\
\hline $\mathrm{t} 0+1$ & $\begin{array}{l}\beta \text { on Parent Age } \\
\beta \text { on Parent Equifax Risk Score } \\
\mathrm{R}^{2}\end{array}$ & $\begin{array}{c}0.0000039 * * \\
-0.0000012^{* * *} \\
0 \%\end{array}$ & $\begin{array}{c}0.00019 * * * \\
-0.00025 * * * \\
3 \%\end{array}$ & $\begin{array}{c}0.00017^{* * *} \\
-0.00025^{* * *} \\
3 \%\end{array}$ & $\begin{array}{c}-0.25 * * * \\
0.33 * * * \\
26 \%\end{array}$ \\
\hline $\mathrm{t} 0+2$ & $\begin{array}{l}\beta \text { on Parent Age } \\
\beta \text { on Parent Equifax Risk Score } \\
\mathrm{R}^{2}\end{array}$ & $\begin{array}{c}0.0000053 * * \\
-0.0000019 * * * \\
0 \%\end{array}$ & $\begin{array}{c}0.000078^{*} \\
-0.00023^{* * *} \\
2 \%\end{array}$ & $\begin{array}{c}0.00017^{* * *} \\
-0.00024^{* * *} \\
3 \%\end{array}$ & $\begin{array}{c}-0.21 * * * \\
0.36 * * * \\
28 \%\end{array}$ \\
\hline $\mathrm{t} 0+3$ & $\begin{array}{l}\beta \text { on Parent Age } \\
\beta \text { on Parent Equifax Risk Score } \\
\mathrm{R}^{2}\end{array}$ & $\begin{array}{c}0.0000044 \\
-0.0000025^{* * *} \\
1 \%\end{array}$ & $\begin{array}{c}0.000066^{* *} \\
-0.00021^{* * *} \\
2 \%\end{array}$ & $\begin{array}{c}0.000048 \\
-0.00023^{* * *} \\
3 \%\end{array}$ & $\begin{array}{c}-0.19 * * * \\
0.38 * * * \\
28 \%\end{array}$ \\
\hline $\mathrm{t} 0+4$ & $\begin{array}{l}\beta \text { on Parent Age } \\
\beta \text { on Parent Equifax Risk Score } \\
\mathrm{R}^{2}\end{array}$ & $\begin{array}{c}-0.0000044 \\
-0.0000031^{* * *} \\
1 \%\end{array}$ & $\begin{array}{c}0.0000054 \\
-0.00019 * * * \\
2 \%\end{array}$ & $\begin{array}{c}0.00011^{* * *} \\
-0.00023^{* * *} \\
2 \%\end{array}$ & $\begin{array}{c}-0.19 * * * \\
0.38 * * * \\
28 \%\end{array}$ \\
\hline $\mathrm{t} 0+5$ & $\begin{array}{l}\beta \text { on Parent Age } \\
\beta \text { on Parent Equifax Risk Score } \\
\mathrm{R}^{2}\end{array}$ & $\begin{array}{c}-0.0000056 \\
-0.0000032^{* * *} \\
0 \%\end{array}$ & $\begin{array}{c}-0.000036 \\
-0.00018 * * * \\
2 \% \\
\end{array}$ & $\begin{array}{c}0.000091^{* *} \\
-0.00021^{* * *} \\
2 \%\end{array}$ & $\begin{array}{c}-0.19 * * * \\
0.39 * * * \\
27 \%\end{array}$ \\
\hline $\mathrm{t} 0+6$ & $\begin{array}{l}\beta \text { on Parent Age } \\
\beta \text { on Parent Equifax Risk Score } \\
\mathrm{R}^{2}\end{array}$ & $\begin{array}{c}0.0000020 \\
-0.0000040^{* * *} \\
1 \%\end{array}$ & $\begin{array}{c}0.000034 \\
-0.00018^{* * *} \\
2 \%\end{array}$ & $\begin{array}{c}0.000065 \\
-0.00020^{* * *} \\
2 \%\end{array}$ & $\begin{array}{l}-0.21 * * * \\
0.38 * * * \\
25 \%\end{array}$ \\
\hline $\mathrm{t} 0+7$ & $\begin{array}{l}\beta \text { on Parent Age } \\
\beta \text { on Parent Equifax Risk Score } \\
\mathrm{R}^{2}\end{array}$ & $\begin{array}{c}0.000010^{*} \\
-0.0000034^{* * *} \\
1 \%\end{array}$ & $\begin{array}{c}0.0000049 \\
-0.00018 * * * \\
2 \%\end{array}$ & $\begin{array}{c}0.00018 * * * \\
-0.00020^{* * *} \\
2 \%\end{array}$ & $\begin{array}{c}-0.21 * * * \\
0.38 * * * \\
24 \%\end{array}$ \\
\hline $\mathrm{t} 0+8$ & $\begin{array}{l}\beta \text { on Parent Age } \\
\beta \text { on Parent Equifax Risk Score } \\
\mathrm{R}^{2}\end{array}$ & $\begin{array}{c}0.000018 * \\
-0.0000032^{* * *} \\
0 \%\end{array}$ & $\begin{array}{c}0.000047 \\
-0.00018^{* * *} \\
2 \%\end{array}$ & $\begin{array}{c}0.000099 * * \\
-0.00021^{* * *} \\
2 \%\end{array}$ & $\begin{array}{c}-0.24 * * * \\
0.37 * * * \\
23 \%\end{array}$ \\
\hline $\mathrm{t} 0+9$ & $\begin{array}{l}\beta \text { on Parent Age } \\
\beta \text { on Parent Equifax Risk Score } \\
\mathrm{R}^{2}\end{array}$ & $\begin{array}{c}-0.0000036 \\
-0.0000031^{* * *} \\
-1 \%\end{array}$ & $\begin{array}{c}0.000076^{*} \\
-0.00017^{* * *} \\
2 \%\end{array}$ & $\begin{array}{c}0.00015^{* *} \\
-0.00020^{* * *} \\
2 \%\end{array}$ & $\begin{array}{c}-0.23 * * * \\
0.36 * * * \\
22 \%\end{array}$ \\
\hline $\mathrm{t} 0+10$ & $\begin{array}{l}\beta \text { on Parent Age } \\
\beta \text { on Parent Equifax Risk Score } \\
\mathrm{R}^{2}\end{array}$ & $\begin{array}{c}-0.000012 \\
-0.0000012 * \\
0 \%\end{array}$ & $\begin{array}{c}-0.0000071 \\
-0.00017^{* * *} \\
2 \%\end{array}$ & $\begin{array}{c}0.00014^{*} \\
-0.00019 * * * \\
2 \%\end{array}$ & $\begin{array}{l}-0.29 * * * \\
0.35 * * * \\
21 \%\end{array}$ \\
\hline
\end{tabular}

Notes: 1) The table shows the children's outcomes at age 20 (t0+1), 21 (t0+2), etc... as a function of parental Equifax Risk Score at age 19. 2) Each column of the table presents results from 10 regressions for the indicated child outcome variable on parental variables indicated and year and zip code fixed effects. 